\title{
HIGH-PRECISION CALIBRATION OF THE RADIOCARBON TIME SCALE, 500-2500 BC
}

\author{
GORDON W PEARSON
}

Palaeoecology Centre, The Queen's University of Belfast, Belfast, Northern Ireland

and

MINZE STUIVER

Department of Geological Sciences and Quaternary Research Center, University of Washington, Seattle, Washington 98195

\section{INTRODUCTION}

This paper is a twin paper to that of Stuiver and Pearson (1986) which covers the time period AD 1950-500 BC. The combined radiocarbon ages of dendrochronologically dated wood presented in this paper covers the time period 500-2500 BC.

Specific discussion of detail effecting only one of the two laboratories is given in the paper which has, as the premier author, the person responsible for the particular laboratory's measurement. Factors effecting both laboratories can be in either paper, but are carefully referenced to the other; outline details are given in both papers.

The construction of a calibration curve from ${ }^{14} \mathrm{C}$ ages with statistically limited precision is not a simple matter. Not only should the standard error in the determination be as small as possible, but the calculation of this error also has to be realistic in that it should account for all variability encountered in the laboratory procedures. Independent dendrochronologic calibration of the samples is also a must. Proof of accuracy has to come from a comparison of the results obtained in two or more facilities. It will be shown that the results obtained in Seattle and in Belfast on wood of the same age, but from different regions, give consistent replication within the quoted error over the entire interval. The aspects of replication are first discussed, and are followed by the details of calibration (Fig 1, Tables 1, 2).

The problems of quoted errors and the use and limitations of error multipliers are discussed, and recommendations are given for the inclusion of such errors in the reported ${ }^{14} \mathrm{C}$ age.

\section{DENDROCHRONOLOGY AND SAMPLE TREATMENT}

The wood samples used for the Belfast radiocarbon calibration came from deciduous oaks (Quercus petraea and Quercus robur) growing at altitudes $<200 \mathrm{~m}$, in Ireland, Scotland, and England (Pilcher et al, 1984). The 7272-year Belfast chronology consists of the ring patterns of 1035 trees. Replication was the keystone to the production of the absolute dates for the radiocarbon samples; no year is spanned by $<6$ trees; most years are spanned by 20-30 trees. External cross-dating between the Irish chronology and those from England and Germany provided independent checks on its validity (Brown et al, 1986). The samples measured by the Seattle Laboratory were either Douglas Fir from the northwestern United States, Sequoia from California, or German Oak (Table 2) (Stuiver \& Pearson, 1986, twin paper).
The treatment of oak wood samples at Belfast was to first plane the 20 -year blocks of wood (some $180 \mathrm{~g}$ ) into thin shavings. These were then bleached using sodium chlorite in $0.018 \mathrm{~N} \mathrm{HCl}$ raised to a tempertaure of ca $70^{\circ} \mathrm{C}$. This treatment left the samples free from tannins and lignins and close to pure cellulose. Following cellulose preparation samples were charred at $500^{\circ} \mathrm{C}$ to leave a carbon-rich residue ready for combustion to $\mathrm{CO}_{2}$.

The treatment of the Seattle samples (mainly pine) followed one of two different methods detailed in Stuiver and Pearson (1986, twin paper).

TECHNIQUE AND LABORATORY REPRODUCIBILITY

Two different techniques were employed at the Belfast and Seattle laboratories. In Belfast, the oak wood samples were converted to $\mathrm{CO}_{2}$ by combustion and sub-sampled for mass spectrometric measurement of the stable carbon isotope ratio. Benzene was then synthesized from sample $\mathrm{CO}_{2}$ following the conversion path $\mathrm{CO}_{2}-\mathrm{LiC} \rightarrow \mathrm{C}_{2} \mathrm{H}_{2}-\mathrm{C}_{6} \mathrm{H}_{6}$ using the method of Barker (1953). The benzene was then measured using a Philips PW4510 automatic liquid scintillation counter set up as previously described in Pearson $(1979,1983)$. Various corrections were applied to the observed count-rates based on the careful monitoring of internal and external parameters. The application of these corrections simulate a constant counting efficiency such that only one reference standard count-rate was used for the calculation of all the ${ }^{14} \mathrm{C}$ ages reported herein although measured over a period of 10 years. The system did not allow a constant background to be used over this period but corrections applied to the observed background count-rate gave an inaccuracy of $< \pm 0.5 \%$ when used to evaluate a ${ }^{14} \mathrm{C}$ age of about one half-life.

The method used in Seattle was the proportional counting of $\mathrm{CO}_{2}$ and is described more fully in Stuiver and Pearson (1986, twin paper).

The reproducibility of Belfast data is proven by a set of 55 replicate analyses measured over a period of 10 years, some replicates being done within months, others repeated years later. The actual standard deviation $\hat{\sigma}$ in a single measurement (assumed to be all of equal weight) based on 55 replicate analyses was calculated using the relationship $\hat{\sigma}=\sqrt{\mathrm{SS} / 2(\mathrm{n}-1)}$ where $\mathrm{SS}=$ Sum of the (difference between duplicates) ${ }^{2}, \mathrm{n}=55$, and $\hat{\sigma}$ is the derived single measurement standard deviation which can then be compared to the mean standard deviation $(\bar{\sigma})$ quoted on the 110 individual measurements. The actual calculated standard deviation value was $\hat{\sigma}=19.0$ yr. The mean quoted error on the individual measurements was evaluated from $\bar{\sigma}=\Sigma_{\mathrm{i}-1}^{\mathrm{n}} \sigma_{\mathrm{i}} / \mathrm{n}$, and gave a value of $\bar{\sigma}=15.4 \mathrm{yr}$, thus suggesting that the 
quoted error is underestimated by ca $23 \%$, or an error multiplier of 1.23 is required.

The error multiplier of the Seattle laboratory was also determined experimentally in two ways: 1) from the comparison of 30 pairs of wood samples from different trees giving an error multiplier of 1.53 , and 2) repeated measurement on outlying samples yielded an error multiplication of 1.62. Both of these values were demonstrated to be maximum values, and a value of 1.60 was taken to be a reasonable estimate and perhaps still rather generous. Additional details are given in Stuiver and Pearson (1986).

\section{SYSTEMATIC DIFFERENCES BETWEEN LABORATORIES AND} COMPARISON OF VARIANCE

The systematic ${ }^{14} \mathrm{C}$ age differences between the Belfast and Seattle laboratories have a maximum difference of only a few years (Stuiver \& Pearson, 1986, twin paper). The weighted mean ${ }^{14} \mathrm{C}$ age difference of the Belfast and Seattle bi-decadal data set is $0.6 \pm 1.6 \mathrm{yr}$ (number of comparisons $\mathrm{n}=214)$. For the $\mathrm{AD}$ interval the difference is $2.6 \pm 2.3 \mathrm{yr}(\mathrm{n}=90)$ and for the $\mathrm{BC}$ portion it is $3.4 \pm 2.1(\mathrm{n}=124)$.

The ${ }^{14} \mathrm{C}$ ages of wood of the same age for Ireland, south Germany and northwestern United States differ on average by only a few years (Stuiver \& Pearson, twin paper).

It is shown (Stuiver \& Pearson, 1986, twin paper) that the quoted laboratory standard deviations account for almost all the differences found between the two data sets.

\section{CONSTRUCTION OF RADIOCARBON AGE CALIBRATION CURVES}

The calibration curves were constructed from the set of ${ }^{14} \mathrm{C}$ ages obtained for samples each spanning a 20-yr interval, with some exceptions as noted in the Table 1 heading. The cal $\mathrm{AD} / \mathrm{BC}$ (or cal $\mathrm{BP}$ ) ages follow the mid-points of the Belfast bi-decadal series whenever possible, starting in AD 1840. The AD 1940-AD 1860 data set is based on the Seattle data alone; all other ${ }^{14} \mathrm{C}$ ages are based on the weighted Belfast/Seattle averages except when Belfast skipped a decade. Here the gaps were filled by averaging $30-y \mathrm{r}$ blocks of Seattle data (see Table 1).

As discussed previously, the standard deviations in the ${ }^{14} \mathrm{C}$ age determinations of each laboratory are based on the reproducibility of the measurements within each laboratory and are larger than the errors usually quoted by both laboratories. For Belfast, where additional factors are used to calculate the routinely reported standard deviation beyond the counting statistics, the reproducibility tests indicate an error multiplier of 1.23. For Seattle, where the routinely reported standard deviations include only the error derived from counting statistics, the error multiplier is 1.6.

The standard deviation assigned to the curve (the vertical difference between center and outer curve) accounts for nearly $90 \%$ of the demonstrated standard deviation in the ${ }^{14} \mathrm{C}$ age differences of both laboratories. The mean standard deviation reported with the curves is $12.1 \mathrm{yr}$ and is solely based on the Belfast and Seattle measuring reproducibility. The vari- ance in the differences in ${ }^{14} \mathrm{C}$ ages of contemporaneous samples measured independently in Belfast and Seattle indicate a measure of uncertainty that is equivalent with an average standard deviation of $13.4 \mathrm{yr}$.

The wood used for the ${ }^{14} \mathrm{C}$ measurements came from the western United States, Ireland, and southern Germany (Table 2). Oak wood was used for the European chronologies (Becker, 1983; Pilcher et al, 1984) and Douglas Fir and Sequoia for the US portion. In the preceding sections it was shown that contemporaneous wood from these trees differed, on average, by only a few ${ }^{14} \mathrm{C}$ years. Thus, although the curves are based on wood from different trees, identical results would have been obtained if all measurements had been made on a single tree from one locality.

THE AGE ERROR REPORTED WITH THE RADIOCARBON DATE

The international ${ }^{14} \mathrm{C}$ community follows strict calculation procedures when determining a conventional ${ }^{14} \mathrm{C}$ age (Stuiver \& Polach, 1977). Unfortunately, age error calculations are much less bound by rules.

The error in any laboratory determination is a composite of 1) The Poisson statistical error based on the number of counts observed for sample and standards, assuming constant counting conditions, and 2) the errors associated with factors that cause deviation from the above constant counting conditions and other non-systematic errors which affect the reproducibility of the laboratory results. The latter can be derived from replicate sample measurements. Attempts to determine systematic errors are rarely made by the ${ }^{14} \mathrm{C}$ community. The reported sample age error (one standard deviation) is often based solely on Poisson statistics in the number of registered sample and standard counts. Such a substitute for a repeatmeasurement derived standard deviation leads to an underestimate because it neglects other factors that add to the variance (Pearson, 1979, 1983).

When identical tree-ring samples (with approximate ages of ca 5000 ${ }^{14} \mathrm{C}$ yr) were measured by 20 laboratories (International Study Group, 1982 ) it was found that the reproducibility standard deviations in the submitted data set were substantially higher than the age errors reported by the laboratories. Systematic errors ranged from $<20 \mathrm{yr}$ (3 laboratories) to 200 yr (1 laboratory).

When comparing the reproducibility standard deviation (obtained after removal of off-sets from the data set) with the laboratory reported error $\sigma$ it was found that $\sigma$ has to be multiplied with 1.3 for $\sigma<20 \mathrm{yr}$, with ca 2.0 for $\sigma$ in the 20- to 80-yr range, and with 1.0 for $\sigma>80 \mathrm{yr}$ (International Study Group). These multipliers are strictly laboratory-related and in principle independent of the magnitude of $\sigma$. Additional information on systematic errors is available for a set of samples in the 7000 to $8000{ }^{14} \mathrm{C} \mathrm{yr}$ range measured in Seattle, La Jolla, Heidelberg, and Tucson (Stuiver et al, 1986). Off-sets of $29 \pm 10,27 \pm 12$ and $52 \pm 8$ yr were found, respectively, for Seattle-La Jolla, Seattle-Heidelberg, and Seattle-Tucson comparisons.

The above studies indicate that systematic errors may exist, and that the reported standard deviation of a ${ }^{14} \mathrm{C}$ age measurement is usually too low. The degree of under-reporting has only been determined so far for 20 
odd laboratories for samples ca $5000{ }^{14} \mathrm{C}$ yr old. Unfortunately, the error multipliers determined in the above international group study cannot be applied to all age ranges because the multiplier values are age dependent (Stuiver $e t a l, 1986$ ). Error multipliers also may change from year to year (or even day to day) at a specific laboratory with improving (or deteriorating) experimental conditions. It is recommended that the user of a ${ }^{14} \mathrm{C}$ date obtain additional information on reproducibility and systematic error determinations from the reporting laboratory. This information should lead to a realistic standard deviation in the age (based on repeat measurements of test samples) although care must be taken in its use particularly when determining $2 \sigma$ and $3 \sigma$ probabilities. Limitations on systematic error size also should be provided. A systematic error, of course, should not be part of the regular \pm reported with the date.

In the absence of the above information, the user can only take as the ${ }^{14} \mathrm{C}$ age error the actual reported $\sigma$, with the understanding that this error is usually too small. In case the user would take twice the reported standard deviation it should be realized that 1) for some laboratories the actual error may be smaller than $2 \sigma$, and 2) statistical rules (such as stating that only 1 event out of 20 would be outside $2 \sigma$ bounds) are not valid because, after all, the original $\sigma$ is not a properly defined standard deviation in many instances.

\section{CALIBRATION INSTRUCTIONS}

The Figure 1 calibration curves consist of three lines. The center line is the actual calibration curve whereas the outer lines indicate the one sigma (standard deviation) uncertainty in the calibration curve. The calibration curve depicts the (non-linear) transformation of ${ }^{14} \mathrm{C}$ ages to calibrated $\mathrm{AD} /$ $\mathrm{BC}$ (or BP) ages. The nomenclature adopted for the dendro (calendar) year time scale is cal $\mathrm{AD} / \mathrm{BC}$ or cal $\mathrm{BP}$. The cal $\mathrm{AD} / \mathrm{BC}$ ages are plotted along the lower horizontal axis and the cal BP ages along the upper one.

Cal BP ages are relative to the year AD 1950, with 0 cal BP equal to AD 1950. The relationship between cal $\mathrm{AD} / \mathrm{BC}$ and cal $\mathrm{BP}$ ages is simple: $\mathrm{cal} \mathrm{BP}=$ 1950 - cal AD, and cal BP = $1949+$ cal BC. The switch from 1950 to 1949 when converting $\mathrm{BC}$ ages is caused by the absence of the zero year in the $\mathrm{AD} / \mathrm{BC}$ chronology (when progressing from $1 \mathrm{BC}$ to $1 \mathrm{AD}$, the cal $\mathrm{BP}$ ages should be without a gap).

The conversion of a ${ }^{14} \mathrm{C}$ age to a cal age is straightforward: 1) Draw a horizontal (parallel to the bottom axis) line (A) through the ${ }^{14} \mathrm{C}$ age to be converted, and 2) draw vertical lines through the intercept(s) of line A and the calibration curve (center line). The cal $\mathrm{AD} / \mathrm{BC}$ ages can be read at the bottom axis, the cal BP ages at the top. A single ${ }^{14} \mathrm{C}$ age can correspond with multiple cal ages, due to past changes in atmospheric ${ }^{14} \mathrm{C}$ levels (see Stuiver, 1982 for illustration)

The user has to determine the calibrated ages from the Figure 1 graphs by drawing lines. An alternate approach is the use of Table 2, where the cal ages are listed for ${ }^{14} \mathrm{C}$ ages that increase by 20 -yr steps. Obviously, the user has to interpolate between the 20 -yr steps of ${ }^{14} \mathrm{C}$ ages and sigmas if further fine tuning is desired.
The conversion of the standard error in the ${ }^{14} \mathrm{C}$ age into a range of cal $\mathrm{AD} / \mathrm{BC}(\mathrm{BP})$ ages is more complicated. The user should first determine whether he/she wants to use 1) the laboratory quoted error (see previous section for a discussion) or 2) increase the quoted error by a known "error multiplier." Once the sample $\sigma$ has been targeted, the curve $\sigma$ (one standard deviation) should be read from the calibration curve by taking the difference in radiocarbon years between center curve and outer curve(s) in Figure 1. The curve $\sigma$ and sample $\sigma$ should then be used to calculate total $\sigma=$ $\sqrt{(\text { sample } \sigma)^{2}+(\text { curve } \sigma)^{2}}$ (Stuiver, 1982)

Horizontal lines should now be drawn through the ${ }^{14} \mathrm{C}$ age + total $\sigma$, and ${ }^{14} \mathrm{C}$ age - total $\sigma$ value. The vertical lines, drawn through the intercepts with the CENTRAL curve, yield the outer limits of possible cal AD/BC (or $\mathrm{BP})$ ages that are compatible with the sample standard deviation.

The above procedure was used to derive the "ranges" of cal AD/BC (BP) ages listed in Table 2.

The conversion procedure yields 1) single or multiple cal AD/BC (BP) ages that are compatible with a certain ${ }^{14} \mathrm{C}$ age, and 2) the range(s) of cal ages that corresponds to the standard deviation in the ${ }^{14} \mathrm{C}$ age. The probability that a certain cal age is the actual sample age may be quite variable within the cal age range. Higher probabilities are encountered around the intercept ages. Low, or near zero probabilities are encountered when part of the calibration curve 'snakes' outside the total $\sigma$ boundaries. The nonlinear transform of a Gaussian standard deviation around a ${ }^{14} \mathrm{C}$ age into cal $\mathrm{AD} / \mathrm{BC}(\mathrm{BP})$ ages leads to a very complex probability distribution that can only be calculated with the aid of computers. We are currently developing suitable programs for these probability calculations, and plan to make these programs available in the near future.

The calibration data presented in this paper are to be used for samples formed in isotopic $\left({ }^{14} \mathrm{C}\right)$ equilibrium with atmospheric $\mathrm{CO}_{2}$. Although the wood samples were collected from specific regions (Ireland, Germany, and western USA) the calibration data can be used for a large part of the Northern Hemisphere (Stuiver, 1982). However, systematic age differences are possible for Southern Hemispheric samples where ${ }^{14} \mathrm{C}$ ages of wood samples tend to be ca 30 yr older (Lerman, Mook \& Vogel, 1970; Vogel, Fuls \& Visser, 1986). Thus, ${ }^{14} \mathrm{C}$ ages of Southern Hemispheric samples should be reduced by 30 years before being converted into a cal $\mathrm{AD} / \mathrm{BC}$ (BP) age.

\section{SMOOTHING OF THE CALIBRATION CURVE}

The Figure 1 points have a $20-\mathrm{yr}$ time separation, $i e$, the calibration points are the mid-points of wood samples spanning 20 years. Samples submitted for dating may cover shorter (eg, seed samples) or longer intervals (eg, lake sediment samples). The decadal calibration results of the Seattle laboratory are available when better time resolution is needed (Stuiver \& Becker, 1986). If less resolution is desired, the Figure 2 curves can be used. Here, a 5-point moving average (usually identical with a 100 -yr moving average of the Figure 1 data set) was used to construct the curves. A single line is given in Figure 2 because the uncertainty in the 5 point moving average is only a few radiocarbon years. The instructions for determining the 
cal $\mathrm{AD} / \mathrm{BC}(\mathrm{BP})$ ages are listed in the preceding section. Samples falling outside the ranges covered by the twin papers (Stuiver \& Pearson, 1986; Pearson \& Stuiver, 1986) can be provisionally converted using the curves provided by Pearson et al (1986) employing the same method outlined above.

\section{MARINE SAMPLE AGES}

The calibraton curves should be applied only for age conversion of samples that were formed in equilibrium with atmospheric $\mathrm{CO}_{2}$. Conventional ${ }^{14} \mathrm{C}$ ages of materials not in equilibrium with atmospheric reservoirs do not take into account the off-set in ${ }^{14} \mathrm{C}$ age that may occur (Stuiver \& Polach, 1977). This off-set, or reservoir deficiency, has to be deducted from the reported ${ }^{14} \mathrm{C}$ age before any attempt can be made to convert to cal $\mathrm{AD} /$ $\mathrm{BC}(\mathrm{BP})$ ages. The reservoir deficiency is time dependent for the mixed layer of the ocean. Model calculated calibration curves for marine samples are listed separately in this volume (Stuiver, Pearson \& Braziunas, 1986).

\section{ACKNOWLEDGMENTS}

G W Pearson would like to thank all members past and present of the ${ }^{14} \mathrm{C}$ laboratory who participated in this research. Particular thanks are given to $S$ Hoper who has been responsible for the routine analysis of samples over the last two years and to D Brown who has been responsible for the selection and isolation of dendrochronologically dated wood samples supplied by J R Pilcher and M G L Baillie. Thanks are also given to D Corbett and $\mathrm{F}$ Qua for their conscientious assistance in this project.

Thanks are due SERC for a grant to G W Pearson to carry out this research.

P J Wilkinson dedicated much time and care to the Seattle high-precision measurements. P J Reimer's computer virtuosity was of critical importance for producing the graphs, tables, and statistical analysis.

Nearly all BC determinations at Seattle were on German Oak generously supplied (and dendro-dated) by Bernd Becker, University of Hohenheim (Stuttgart), West Germany. Dendrochronologic determinations were also made by M Parker, Vancouver, BC, Canada, D Eckstein, University of Hamburg, West Germany, and H Garfinkel, University of Washington.

The manuscript benefitted substantially from the scientific advice given by $\mathrm{P}$ M Grootes, University of Washington. The radiocarbon mea- surements of the Seattle Laboratory were supported through the National Science Foundation grants ATM-8318665 of the Climate Dynamics Program, and EAR-81 15994 of the Environmental Geosciences program.

\section{REFERENCES}

Barker, H, 1953, Radiocarbon dating: Large scale preparation of acetylene from organic material: Nature, v 172, p 631-632.

Becker, B, 1983, The long-term radiocarbon trend of the absolute oak tree-ring chronology, 2800-800 BC, in Stuiver, $\mathrm{M}$ and Kra, R S, eds, Internatl ${ }^{14} \mathrm{C}$ conf, 11 th, Proc: Radiocarbon, v 25, no. 2, p 197-203.

Brown, D M, Munro, M A R, Baillie, M G L and Pilcher, J R, 1986, Dendrochronology-the absolute Irish standard, in Stuiver, $M$ and Kra, R S, eds, Internatl ${ }^{14} \mathrm{C}$ conf, 12 th, Proc: Radiocarbon, $v 28$, no. 2A.

International Study Group, 1982, An inter-laboratory comparison of radiocarbon measurements in tree rings: Nature, v 298, p 619-623.

Lerman, J C, Mook, W G and Vogel, J C, 1970, $\mathrm{C}^{14}$ in tree rings from different localities, in Olsson, IU, ed, Radiocarbon variations and absolute chronology, Nobel symposium, 12th, Proc: New York, John Wiley \& Sons, p 275-299.

Pearson, G W, 1979, Precise ${ }^{14} \mathrm{C}$ measurement by liquid scintillation counting: Radiocarbon, $v$ 21 , no. 1, p $1-21$.

applied to radiocarbon timescale calibration, in Stuiver, M and Kra, R S, eds, Internatl ${ }^{14} \mathrm{C}$ conf, 10th, Proc: Radiocarbon, v 22, no. 2, p 337-345.

- (ms) 1983, The development of high precision ${ }^{14} \mathrm{C}$ measurement and its application to archaeological time-scale problems: PhD dissert, The Queen's Univ Belfast.

Pearson, G W, Pilcher, J R, Baillie, M G L, Corbett, D M and Qua, F, 1986, High-precision ${ }^{14} \mathrm{C}$ measurement of Irish oaks to show the natural ${ }^{14} \mathrm{C}$ variations from $\mathrm{AD} 1840-5210 \mathrm{BC}$, in Stuiver, $\mathrm{M}$ and Kra, R S, eds, Internatl ${ }^{14} \mathrm{C}$ conf, 12 th, Proc: Radiocarbon, this issue.

Pilcher, J R, Baillie, M G L, Schmidt, B and Becker, B, 1984, A 7,272-year tree-ring chronology for western Europe: Nature, v 312, p 150-152.

Stuiver, M, 1982, A high-precision calibration of the AD radiocarbon time scale: Radiocarbon, $\mathrm{v} 24$, no. $1, \mathrm{p} 1-26$.

Stuiver, $M$ and Becker, B, 1986, A decadal high-precision calibration curve, in Stuiver, $M$ and Kra, R S, eds, Internatl ${ }^{14} \mathrm{C}$ conf, 12 th, Proc: Radiocarbon, this issue.

Stuiver, M, Kromer, B, Becker, B and Ferguson, C W, 1986, ${ }^{14} \mathrm{C}$ age calibration back to 13,300 yr BP and the ${ }^{14} \mathrm{C}$ age matching of the German oak and US bristlecone pine chronologies, in Stuiver, $\mathrm{M}$ and Kra, R S, eds, Internatl ${ }^{14} \mathrm{C}$ conf, 12th, Proc: Radiocarbon, this issue.

Stuiver, M and Pearson, G W, 1986, High-precision calibration of the radiocarbon time scale, AD 1950-500 BC, in Stuiver, $M$ and Kra, R S, eds, Internatl ${ }^{14} \mathrm{C}$ conf, 12 th, Proc: Radiocarbon, this issue.

Stuiver, M, Pearson, G W and Braziunas, T, 1986, Radiocarbon age calibration of marine samples, in Stuiver, $M$ and Kra, R S, eds, Internatl ${ }^{14} \mathrm{C}$ conf, 12 th, Proc: Radiocarbon, this

Stuiver, M and Polach, H A, 1977, Discussion: Reporting of ${ }^{14} \mathrm{C}$ data: Radiocarbon, v 19, no.
. 3, p 355-363.

Vogel, J C, Fuls, A and Visser, E, 1986, Radiocarbon fluctuations during the 3rd millennium BC, in Stuiver, $M$ and Kra, R S, eds, Internatl ${ }^{14} \mathrm{C}$ conf, 12 th, Proc: Radiocarbon, this issue. 


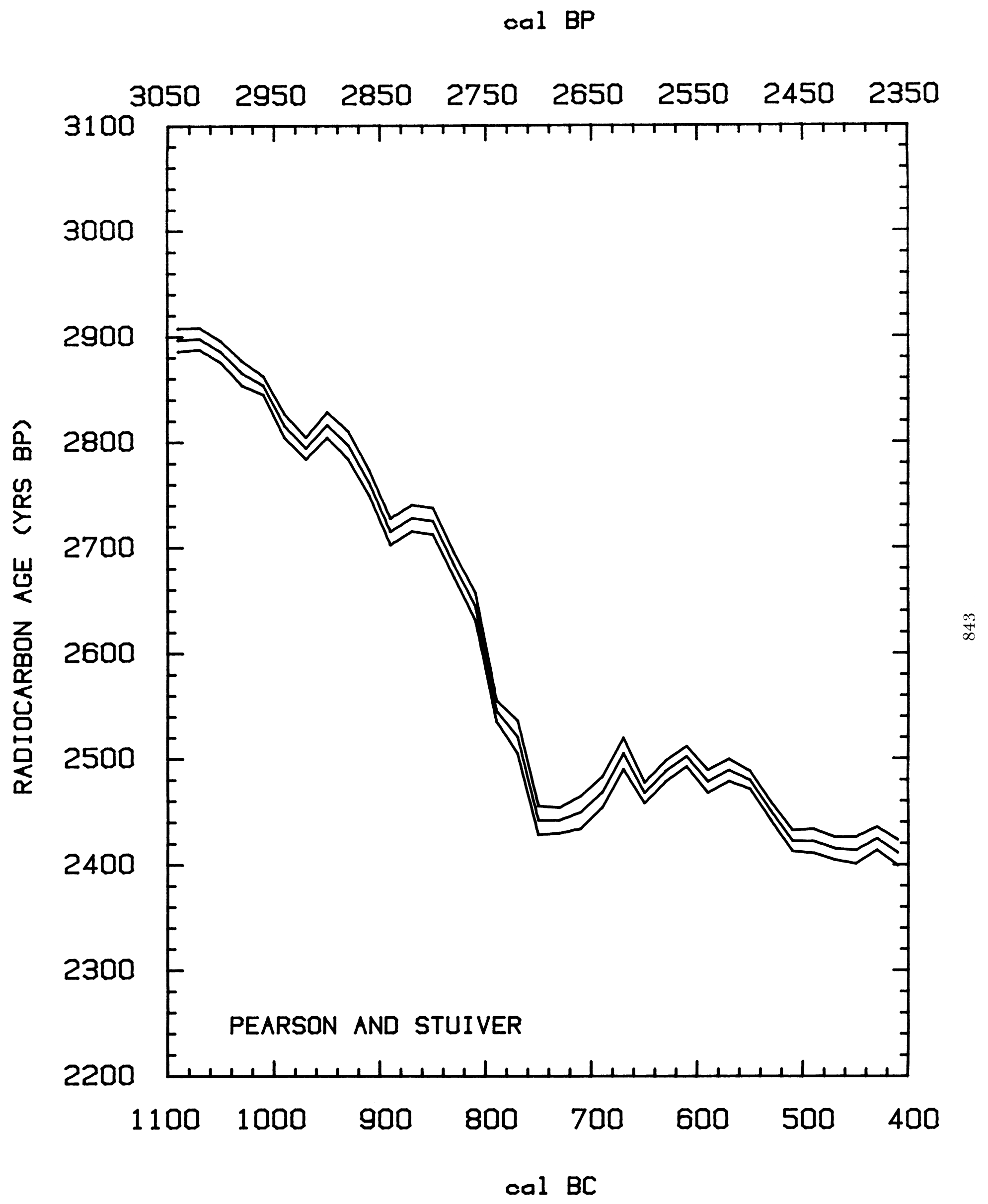

Fig 11 
cal BP

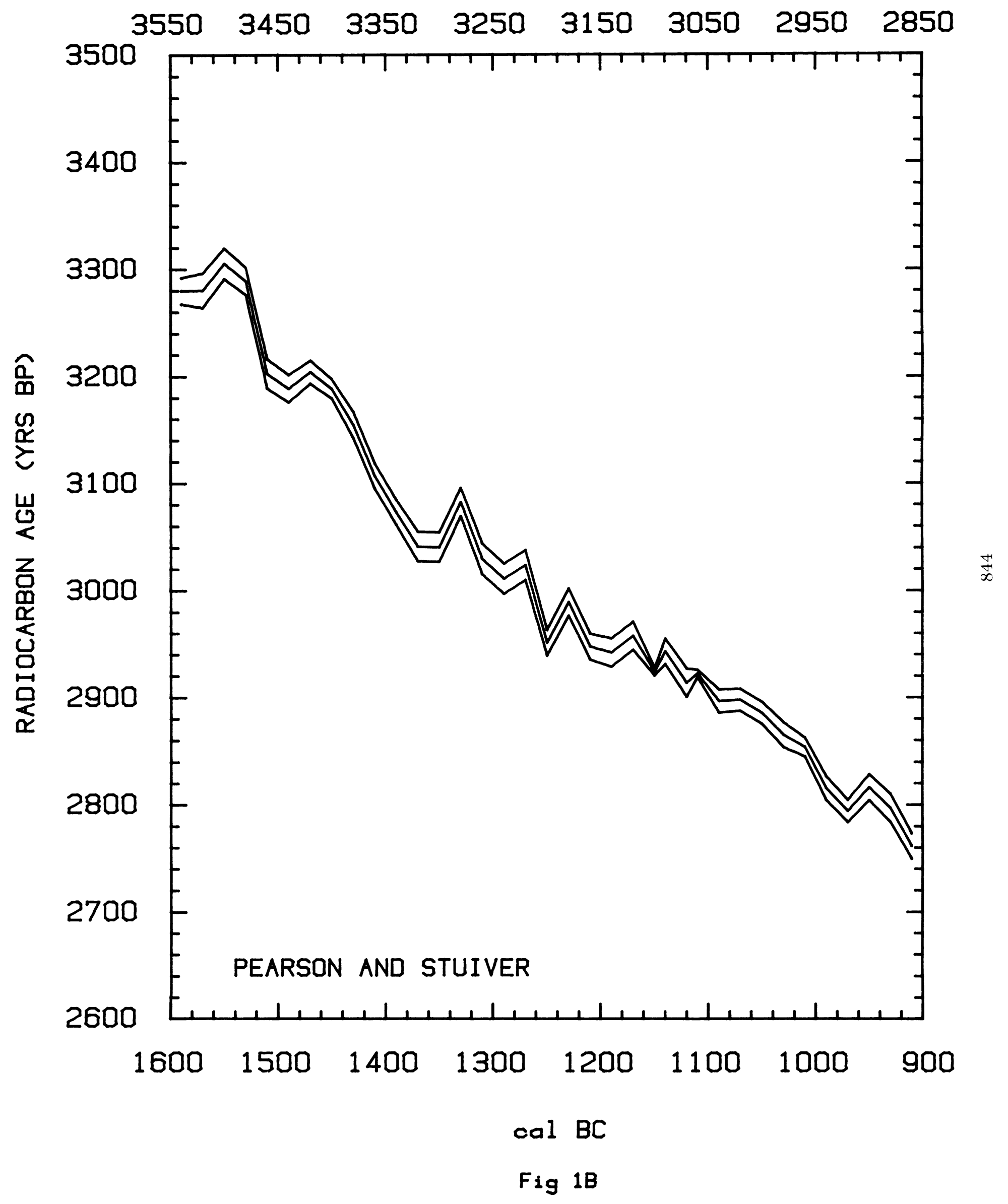


cal BP

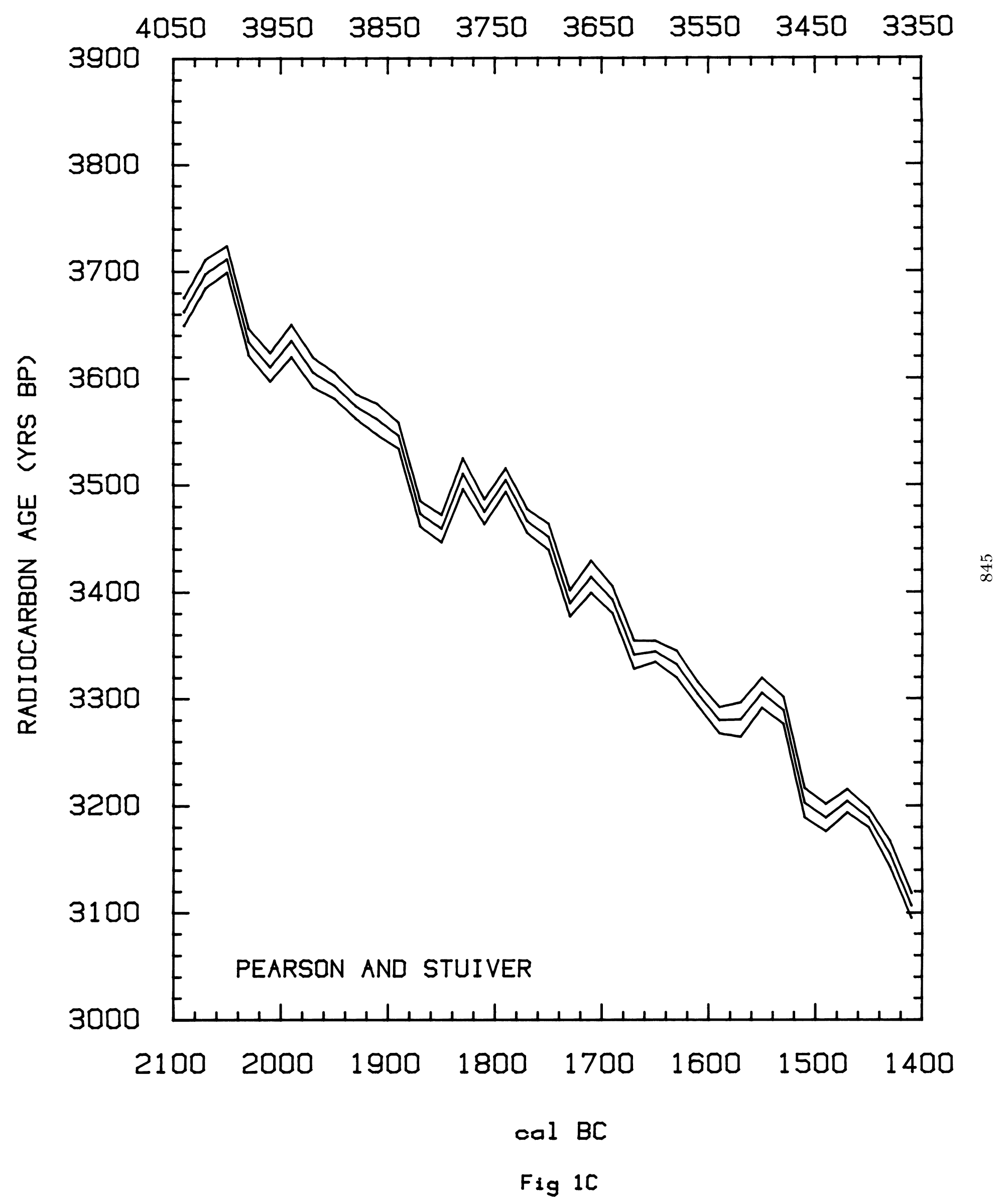


cal BP

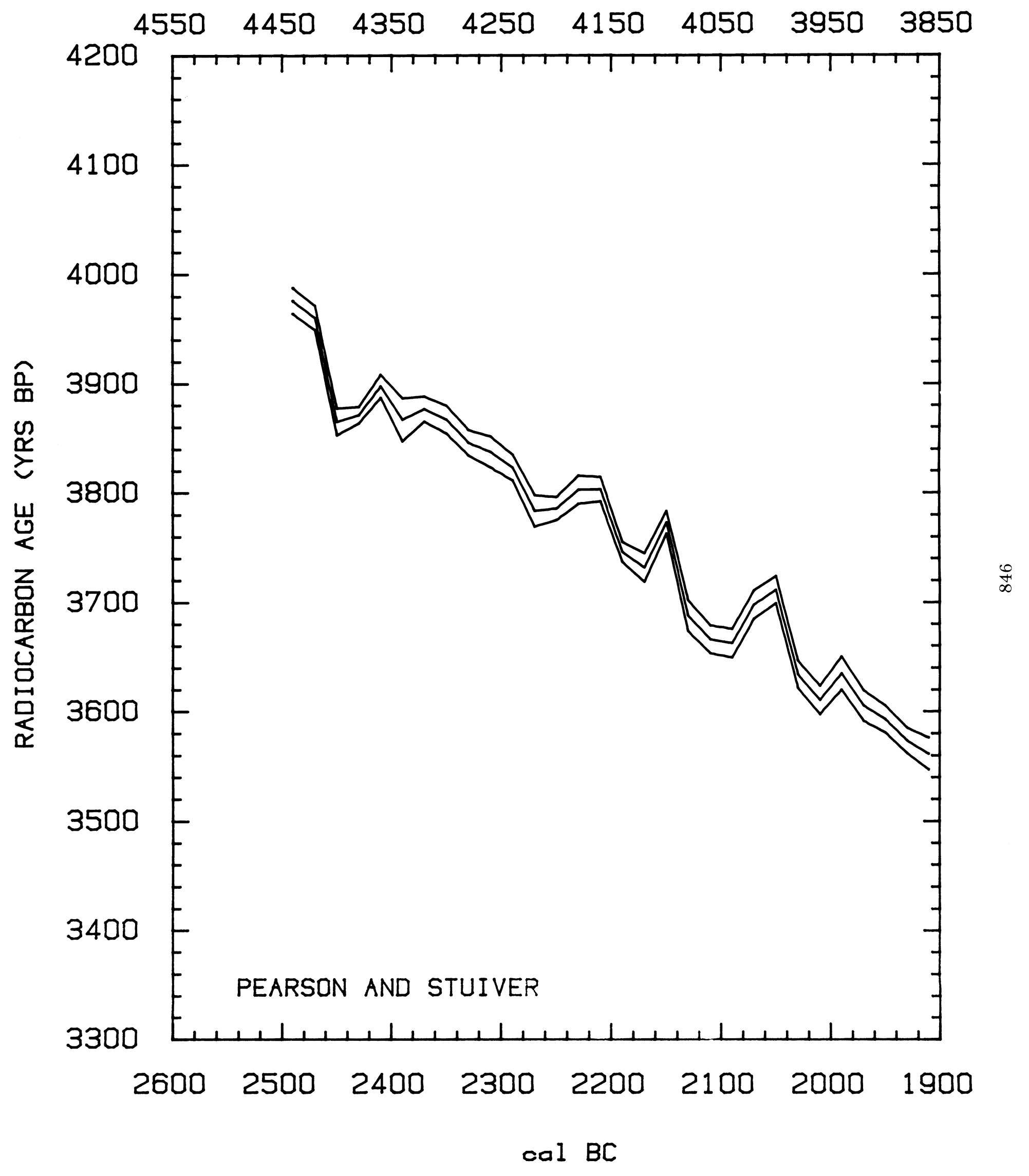

Fig 10 
cal BP

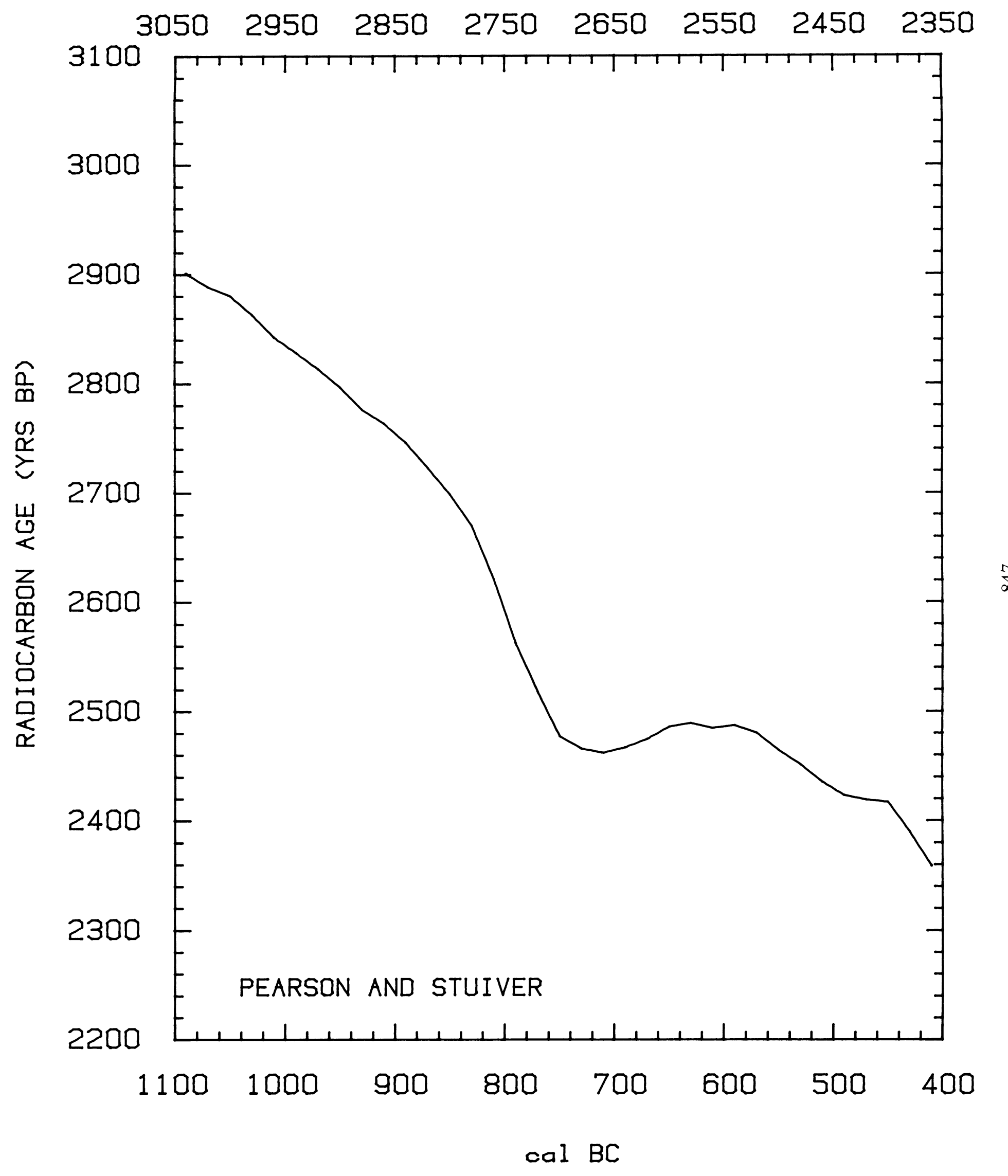

Fig $2 A$ 
cal BP

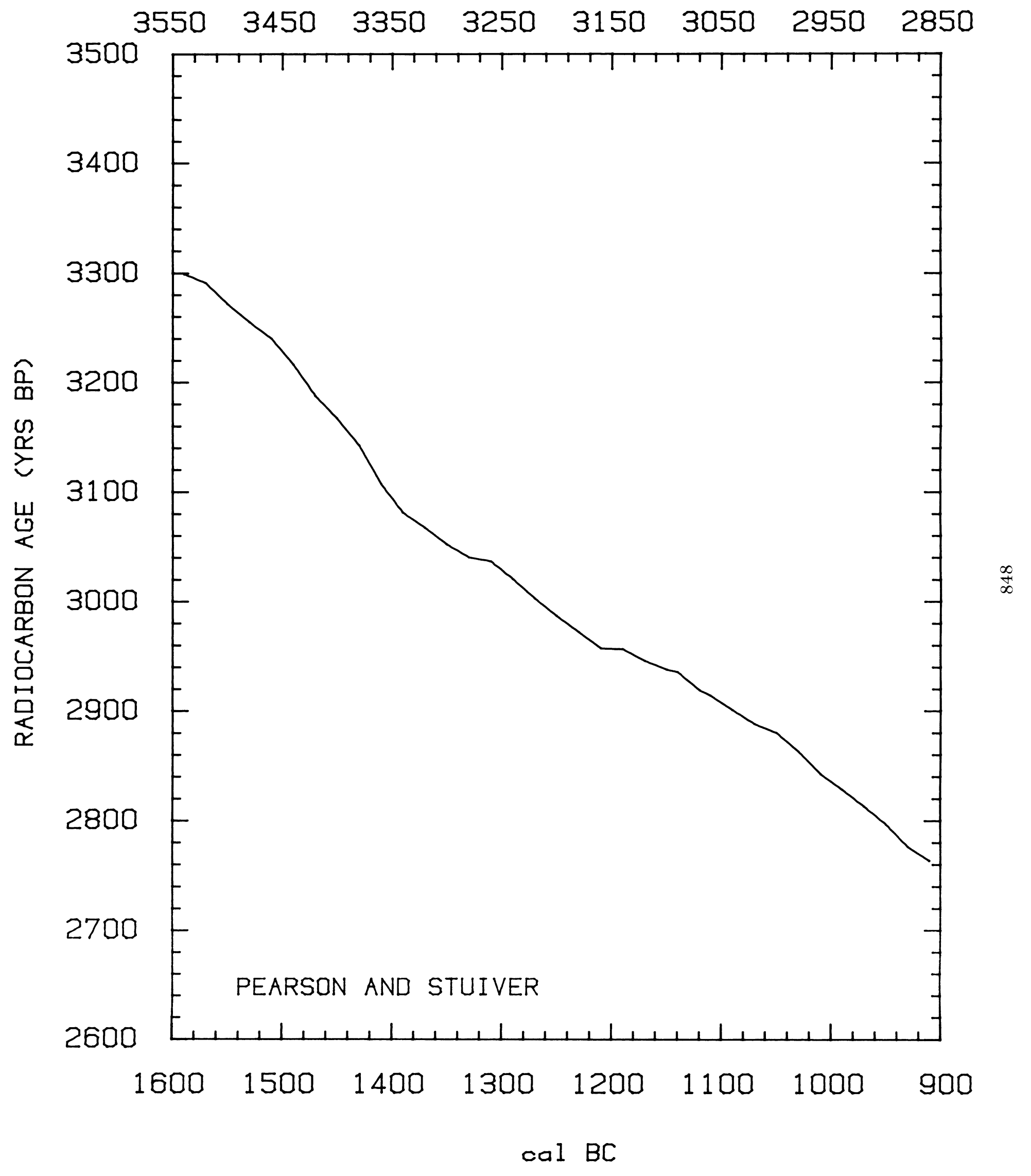

Fig 2B 
$\operatorname{cal} \mathrm{BP}$

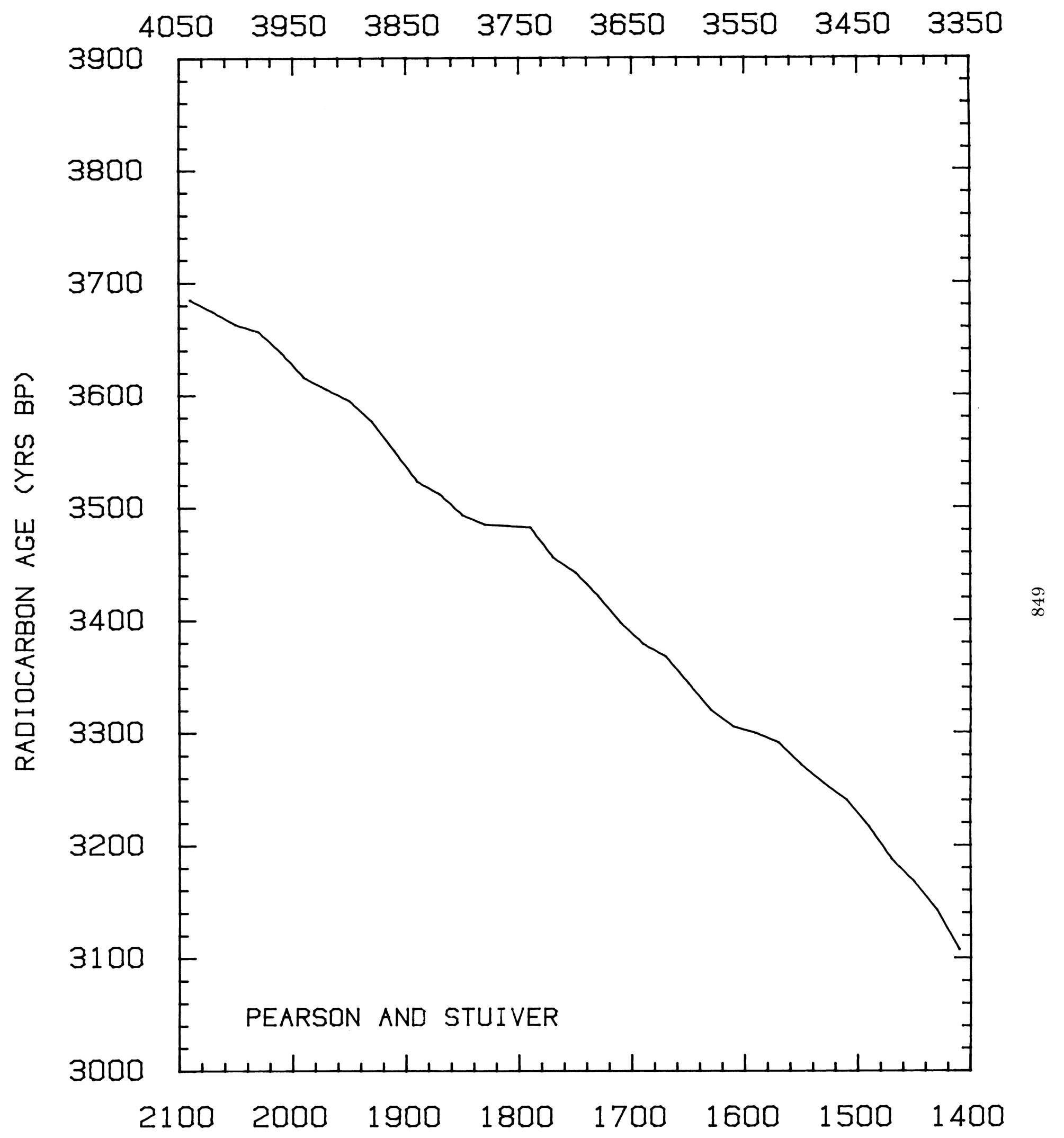

cal BC

Fig 2C 
cal BP

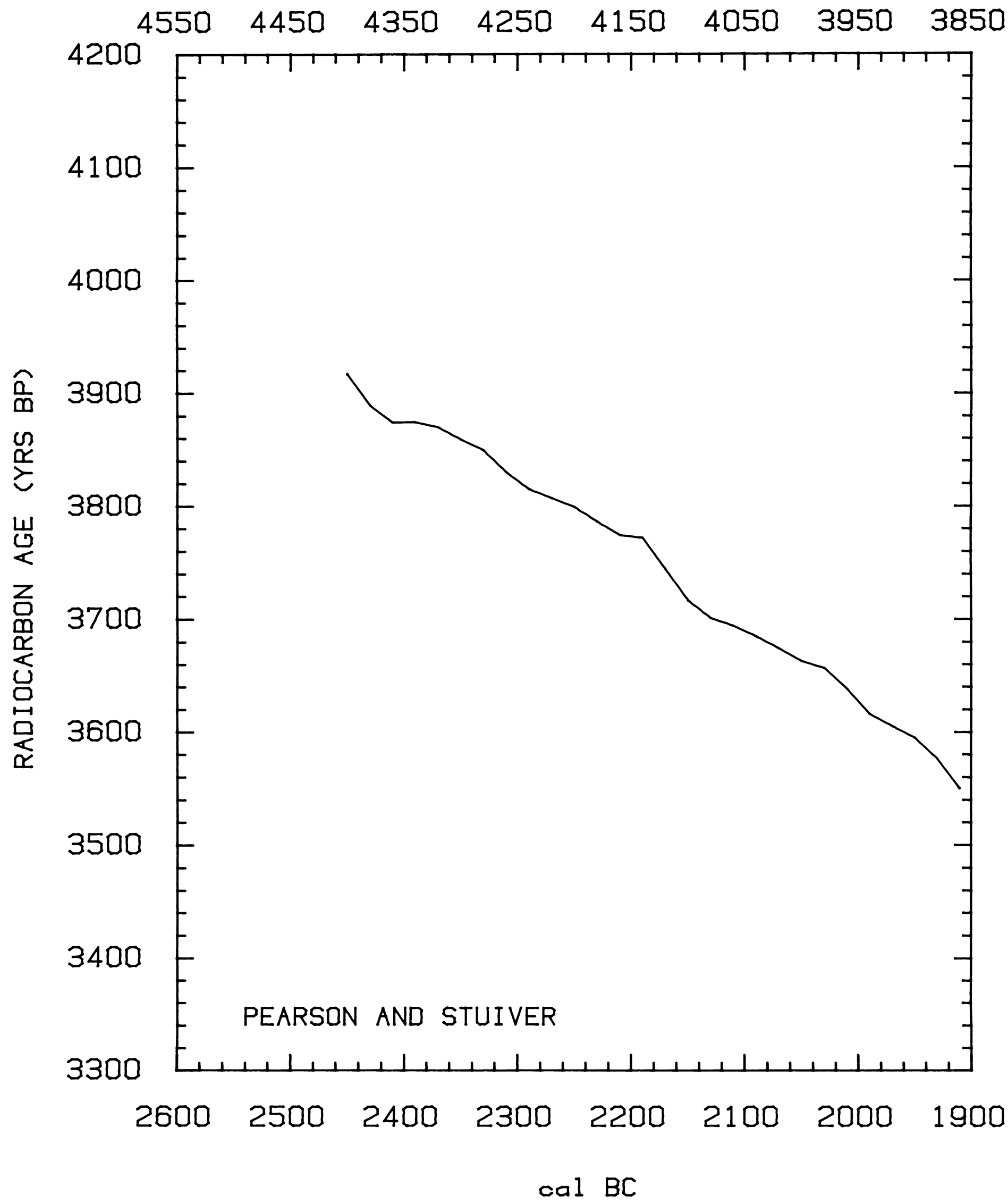

Fig 2D 
TABLE 1-A

TABLE 1-B

The radiocarbon ages are the averages of age determinations made at the University of Belfast and the University of Washington (Seattle). The cal $\mathrm{AD} / \mathrm{BC}$ (or cal BP) ages represent the mid-points of bi-decadal wood sections. Belfast data only were used for $670 \mathrm{BC}, 690 \mathrm{BC}, 2390 \mathrm{BC}$, and $2450 \mathrm{BC}$ because Seattle decade measurements were incomplete for these ages.

The cal AD/BC ages follow the mid-points of the Belfast bi-decadal series whenever possible, starting at $510 \mathrm{BC}$. The actual midpoints of the averages were occasionally slightly different. The differences have been neglected because the midpoints of the Seattle sample were always within 1.5 years of the mid-point of the corresponding Belfast sample. The standard deviation in the ages and $\Delta$ values include lab error multipliers of 1.23 for Belfast and 1.6 for Seattle. The trees used and sample treatments are listed in Table 2 (Stuiver \& Pearson, 1986).

\begin{tabular}{|c|c|c|c|c|c|}
\hline $\begin{array}{l}\text { cal } A D / B C \\
\text { cal } B P\end{array}$ & $\Delta^{1{ }^{4}} \mathrm{C}$ & $\begin{array}{c}\text { Radiocarbon } \\
\text { age BP }\end{array}$ & $\begin{array}{l}\text { cal } A D / B C \\
\text { cal } B P\end{array}$ & $\Delta^{1{ }^{4}} \mathrm{C}$ & $\begin{array}{c}\text { Radiocarbon } \\
\text { age BP }\end{array}$ \\
\hline $\begin{array}{ll}C & 510 \\
\text { P } & 2459\end{array}$ & $-4.1 \pm 1.2$ & $2422 \pm 10$ & $\begin{array}{ll}\text { BC } 870 \\
\text { BP }\end{array}$ & $1.5 \pm 1.6$ & $2728 \pm 12$ \\
\hline $\begin{array}{l}\text { BC } 530 \\
\text { BP } 2479\end{array}$ & $-5.0 \pm 1.1$ & $2450 \pm 9$ & $\begin{array}{ll}\text { BC } 890 \\
\text { BP } 2839\end{array}$ & $5.5 \pm 1.6$ & $2715 \pm 12$ \\
\hline $\begin{array}{ll}\text { BC } & 550 \\
\text { BP } & 2499\end{array}$ & $-6.3 \pm 1.0$ & $2480 \pm 8$ & $\begin{array}{l}\text { BC } 910 \\
\text { BP } 2859\end{array}$ & $2.1 \pm 1.5$ & $2761 \pm 12$ \\
\hline $\begin{array}{ll}\text { BC } & 570 \\
\text { BP } & 2519 \\
\end{array}$ & $-5.1 \pm 1.3$ & $2489 \pm 10$ & $\begin{array}{ll}\text { BC } 930 \\
\text { BP } 2879\end{array}$ & $.1 \pm 1.6$ & $2797 \pm 13$ \\
\hline $\begin{array}{l}\mathrm{BC} 590 \\
\text { BP } 2539 \\
\end{array}$ & $-1.4 \pm 1.3$ & $2478 \pm 11$ & $\begin{array}{l}\text { BC } 950 \\
\text { BP } 2899\end{array}$ & $.1 \pm 1.5$ & $2816 \pm 12$ \\
\hline $\begin{array}{ll}\text { BC } 610 \\
\text { BP } 2559\end{array}$ & $-1.9 \pm 1.2$ & $2502 \pm 10$ & $\begin{array}{l}\text { BC } 970 \\
\text { BP } 2919\end{array}$ & $5.3 \pm 1.3$ & $2794 \pm 10$ \\
\hline $\begin{array}{ll}\text { BC } 630 \\
\text { BP } & 2579\end{array}$ & $2.3 \pm 1.2$ & $2488 \pm 10$ & $\begin{array}{l}\text { BC } 990 \\
\text { BP } 2939\end{array}$ & $5.1 \pm 1.4$ & $2815 \pm 11$ \\
\hline $\begin{array}{ll}\text { BC } 650 \\
\text { BP } & 2599\end{array}$ & $7.3 \pm 1.2$ & $2468 \pm 10$ & $\begin{array}{ll}\text { BC } & 1010 \\
\text { BP } & 2959\end{array}$ & $2.7 \pm 1.1$ & $2854 \pm 9$ \\
\hline $\begin{array}{ll}\text { BC } & 670 \\
\text { BP } & 2619\end{array}$ & $5.0 \pm 1.8$ & $2505 \pm 15$ & $\begin{array}{ll}\text { BC } 1030 \\
\text { BP } 2979\end{array}$ & $3.7 \pm 1.4$ & $2865 \pm 12$ \\
\hline $\begin{array}{ll}\text { BC } & 690 \\
\text { BP } & 2639\end{array}$ & $12.1 \pm 1.8$ & $2468 \pm 15$ & $\begin{array}{ll}\text { BC } & 1050 \\
\text { BP } 2999\end{array}$ & $3.6 \pm 1.3$ & $2886 \pm 10$ \\
\hline $\begin{array}{l}B C \quad 710 \\
\text { BP } 2659 \\
\end{array}$ & $16.9 \pm 1.9$ & $2449 \pm 15$ & $\begin{array}{ll}\mathrm{BC} & 1070 \\
\mathrm{BP} & 3019 \\
\end{array}$ & $4.5 \pm 1.3$ & $2898 \pm 10$ \\
\hline $\begin{array}{l}\text { BC } 730 \\
\text { BP } 2679 \\
\end{array}$ & $20.4 \pm 1.5$ & $2442 \pm 12$ & $\begin{array}{ll}\mathrm{BC} & 1090 \\
\mathrm{BP} & 3039 \\
\end{array}$ & $7.1 \pm 1.4$ & $2897 \pm 11$ \\
\hline $\begin{array}{l}\mathrm{BC} 750 \\
\text { BP } 2699 \\
\end{array}$ & $22.8 \pm 1.7$ & $2442 \pm 14$ & $\begin{array}{l}\mathrm{BC} \quad 1110 \\
\mathrm{BP} \quad 3059 \\
\end{array}$ & $6.3 \pm .4$ & $2923 \pm 3$ \\
\hline $\begin{array}{l}\text { BC } 770 \\
\text { BP } 2719 \\
\end{array}$ & $15.3 \pm 1.9$ & $2521 \pm 16$ & $\begin{array}{l}\overline{B C} \quad 1120 \\
\text { BP } 3069 \\
\end{array}$ & $8.6 \pm 1.6$ & $2914 \pm 13$ \\
\hline $\begin{array}{ll}\text { BC } 790 \\
\text { BP } 2739 \\
\end{array}$ & $14.6 \pm 1.2$ & $2545 \pm 10$ & $\begin{array}{l}\text { BC } 1140 \\
\text { BP } \quad 3089 \\
\end{array}$ & $7.3 \pm 1.5$ & $2943 \pm 12$ \\
\hline $\begin{array}{ll}\text { BC } & 810 \\
\text { BP } & 2759 \\
\end{array}$ & 4.6 & $2644 \pm$ & 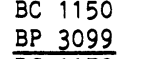 & $11.0 \pm .4$ & $2924 \pm 3$ \\
\hline $\begin{array}{ll}\text { BC } & 830 \\
\text { BP } & 2779 \\
\end{array}$ & & 2683 & $\begin{array}{l}\text { BC } 1170 \\
\text { BP } 3119 \\
\end{array}$ & $9.2 \pm 1.6$ & $2958 \pm 13$ \\
\hline $\begin{array}{ll}B C & 850 \\
\text { BP } & 2799 \\
\end{array}$ & 1.6 & $2725 \pm 13$ & $\begin{array}{l}\overline{B C} 1190 \\
\text { BP } 3139\end{array}$ & $13.6 \pm 1.7$ & $2942 \pm 13$ \\
\hline
\end{tabular}

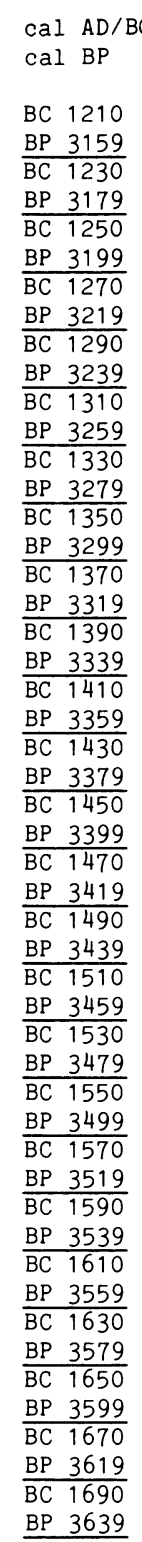

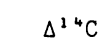

$15.3 \pm 1.5$

$12.5 \pm 1.6$

$19.8 \pm 1.5$

$13.1 \pm 1.7$

$17.1 \pm 1.8$

$17.3 \pm 1.8$

$13.0 \pm 1.6$

$20.8 \pm 1.7$

$23.2 \pm 1.7$

$21.6 \pm 1.4$

$19.8 \pm 1.5$

$16.2 \pm 1.5$

$14.3 \pm 1.1$

$14.8 \pm 1.3$

$19.3 \pm 1.6$

$20.0 \pm 1.7$

$11.5 \pm 1.6$

$11.9 \pm 1.8$

$17.5 \pm 2.0$

$20.1 \pm 1$.

$19.4 \pm 1.4$

$18.3 \pm 1.6$

$19.2 \pm 1.2$

$22.1 \pm 1.6$

$18.0 \pm 1.6$ age $B P$

$2948 \pm 12$

$2989 \pm 13$

$2951 \pm 12$

$3024 \pm 14$

$3011 \pm 14$

$3030 \pm 14$

$3083 \pm 13$

$3041 \pm 14$

$3041 \pm 14$

$3073 \pm 12$

$3107+12$

$3155 \pm 12$

$3204 \pm 11$

$3189 \pm 13$

$3203 \pm 14$

$3289 \pm 13$

$3305 \pm 14$

$3280 \pm 16$

$3280 \pm 12$

$3304 \pm 11$

$3333 \pm 13$

$3344 \pm 10$

$3341 \pm 13$

$3393 \pm 13$ cal BP

\begin{tabular}{ll} 
BC & 1710 \\
BP & 3659 \\
\hline
\end{tabular}

\begin{tabular}{ll} 
BC & 1730 \\
BP & 3679 \\
\hline
\end{tabular}

BP $\quad 3679$

\begin{tabular}{lc} 
BP & 3699 \\
\hline BC & 1770
\end{tabular}

BP $\quad 3719$

\begin{tabular}{ll} 
BP $\quad 3739$ \\
\hline BC & 1810
\end{tabular}

\begin{tabular}{ll} 
BP $\quad 3759$ \\
\hline BC 1830
\end{tabular}

\begin{tabular}{ll} 
BP $\quad 3779$ \\
\hline BC 1850
\end{tabular}

\begin{tabular}{ll} 
BP & 3799 \\
\hline BC & 1870
\end{tabular}

BP 3819

BP 3839

\begin{tabular}{ll} 
BP $\quad 3859$ \\
\hline BC 1930
\end{tabular}

BP 3879

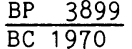

BP 3919

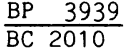

BP 3959

BC 2030

BP 3979

BP 3999

$\begin{array}{lc}\text { BC } & 2070 \\ \text { BP } & 4019\end{array}$

BP 4019

\begin{tabular}{lc} 
BP & 4039 \\
\hline BC & 2110 \\
B & 4059
\end{tabular}

BP 4059

BC 2150

BP 4099

BP 2190

BP 4139

$\begin{array}{cc}\Delta^{14} \mathrm{C} & \begin{array}{r}\text { Radiocarbon } \\ \text { age BP }\end{array} \\ 17.8 \pm 1.8 & 3414 \pm 15 \\ 23.4 \pm 1.5 & 3389 \pm 12 \\ 18.0 \pm 1.5 & 3452 \pm 12 \\ 18.6 \pm 1.4 & 3466 \pm 11 \\ 16.2 \pm 1.4 & 3505 \pm 11 \\ 22.4 \pm 1.4 & 3475 \pm 11 \\ 20.3 \pm 1.8 & 3511 \pm 15 \\ 29.4 \pm 1.6 & 3459 \pm 13 \\ 30.1 \pm 1.5 & 3473 \pm 12 \\ 23.2 \pm 1.5 & 3546 \pm 12 \\ 23.8 \pm 1.8 & 3562 \pm 15 \\ 24.7 \pm 1.4 & 3574 \pm 12 \\ 24.7 \pm 1.5 & 3593 \pm 12 \\ 25.6 \pm 1.7 & 3606 \pm 14 \\ 24.3 \pm 1.9 & 3635 \pm 15 \\ 30.0 \pm 1.6 & 3610 \pm 13 \\ 29.4 \pm 1.5 & 3634 \pm 12 \\ 22.0 \pm 1.5 & 3711 \pm 12 \\ 26.2 \pm 1.6 & 3698 \pm 13 \\ 33.2 \pm 1.6 & 3662 \pm 13 \\ 35.3 \pm 1.6 & 3666 \pm 13 \\ 35.0 \pm 1.8 & 3688 \pm 14 \\ 26.5 \pm 1.3 & 3773 \pm 10 \\ 34.3 \pm 1.6 & 3732 \pm 13 \\ 35.0 \pm 1.1 & 3746 \pm 9\end{array}$


TABLE $1-\mathrm{C}$

\begin{tabular}{|c|c|c|}
\hline $\begin{array}{l}\text { cal AD/BC } \\
\text { cal BP }\end{array}$ & $\Delta^{14} \mathrm{C}$ & $\begin{array}{c}\text { Radiocarbo } \\
\text { age BP }\end{array}$ \\
\hline $\begin{array}{ll}\text { BC } & 2210 \\
\text { BP } & 4159\end{array}$ & $30.1 \pm 1.4$ & $3803 \pm 11$ \\
\hline $\begin{array}{ll}\text { BC } & 2230 \\
\text { BP } & 4179\end{array}$ & $32.7 \pm 1.6$ & $3803 \pm 13$ \\
\hline $\begin{array}{ll}\text { BC } & 2250 \\
\text { BP } & 4199\end{array}$ & $37.4 \pm 1.3$ & $3786 \pm 10$ \\
\hline $\begin{array}{ll}\text { BC } & 2270 \\
\text { BP } & 4219\end{array}$ & $40.2 \pm 1.8$ & $3784 \pm 14$ \\
\hline $\begin{array}{ll}\text { BC } & 2290 \\
\text { BP } & 4239\end{array}$ & $37.6 \pm 1.5$ & $3823 \pm 12$ \\
\hline $\begin{array}{ll}\text { BC } & 2310 \\
\text { BP } & 4259\end{array}$ & $38.2 \pm 1.8$ & $3838 \pm 14$ \\
\hline $\begin{array}{ll}B C & 2330 \\
\text { BP } & 4279\end{array}$ & $39.6 \pm 1.4$ & $3846 \pm 12$ \\
\hline $\begin{array}{ll}\mathrm{BC} & 2350 \\
\mathrm{BP} & 4299 \\
\end{array}$ & $39.4 \pm 1.6$ & $3867 \pm 13$ \\
\hline $\begin{array}{ll}\text { BC } & 2370 \\
\text { BP } & 4319\end{array}$ & $40.7 \pm 1.4$ & $3877 \pm 12$ \\
\hline BC 2390 & $44.5 \pm 2.4$ & $3867 \pm 20$ \\
\hline BP 4339 & & \\
\hline $\begin{array}{ll}\text { BC } & 2410 \\
B P & 4359\end{array}$ & $43.0 \pm 1.3$ & $3898 \pm 11$ \\
\hline $\begin{array}{ll}B C & 2430 \\
B P & 4379\end{array}$ & $49.0 \pm .9$ & $3871 \pm 8$ \\
\hline $\begin{array}{ll}\text { BC } & 2450 \\
\text { BP } & 4399\end{array}$ & $52.4 \pm 1.5$ & $3865 \pm 12$ \\
\hline $\begin{array}{ll}\mathrm{BC} & 2470 \\
\mathrm{BP} & 4419 \\
\end{array}$ & $42.5 \pm 1.4$ & $3960 \pm 11$ \\
\hline $\begin{array}{ll}\text { BC } & 2490 \\
\text { BP } & 4439\end{array}$ & $43.0 \pm 1.5$ & $3976 \pm 12$ \\
\hline
\end{tabular}

TABLE 2

The conversion of the radiocarbon ages to a series of ranges of cal $\mathrm{AD} / \mathrm{BC}$ (and $\mathrm{BP})$ dates is determined by the $\mathrm{AD} / \mathrm{BC}$ intercepts of the sample radiocarbon age \pm $\sqrt{(\text { sample } \sigma)^{2}+(\text { curve } \sigma)^{2}}$ and the calibration curve. Intercepts of the radiocarbon age with the calibration curve are listed to the right. Sample $\sigma$ is the standard error in the radiocarbon age.

For sample sigmas and ranges larger or equal to 100 years the data were rounded to the nearest decade. When the gap between two successive ranges was less than 10 years, the two ranges were combined to a single one. Illustrations of the above are given below.

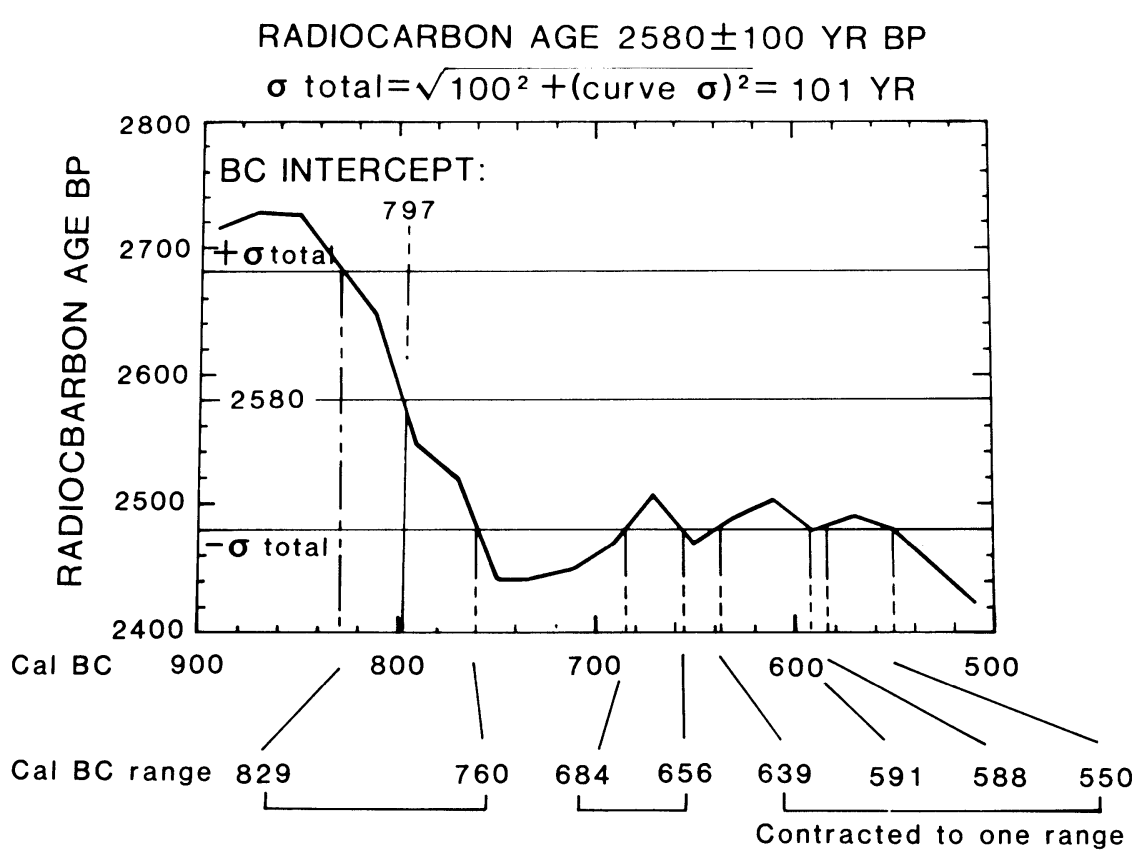


RADIOCARBON AGE $120 \pm 20$ YR BP

$\sigma$ total $=\sqrt{20^{2}+(\text { curve } \sigma)^{2}}=21 \mathrm{YR}$

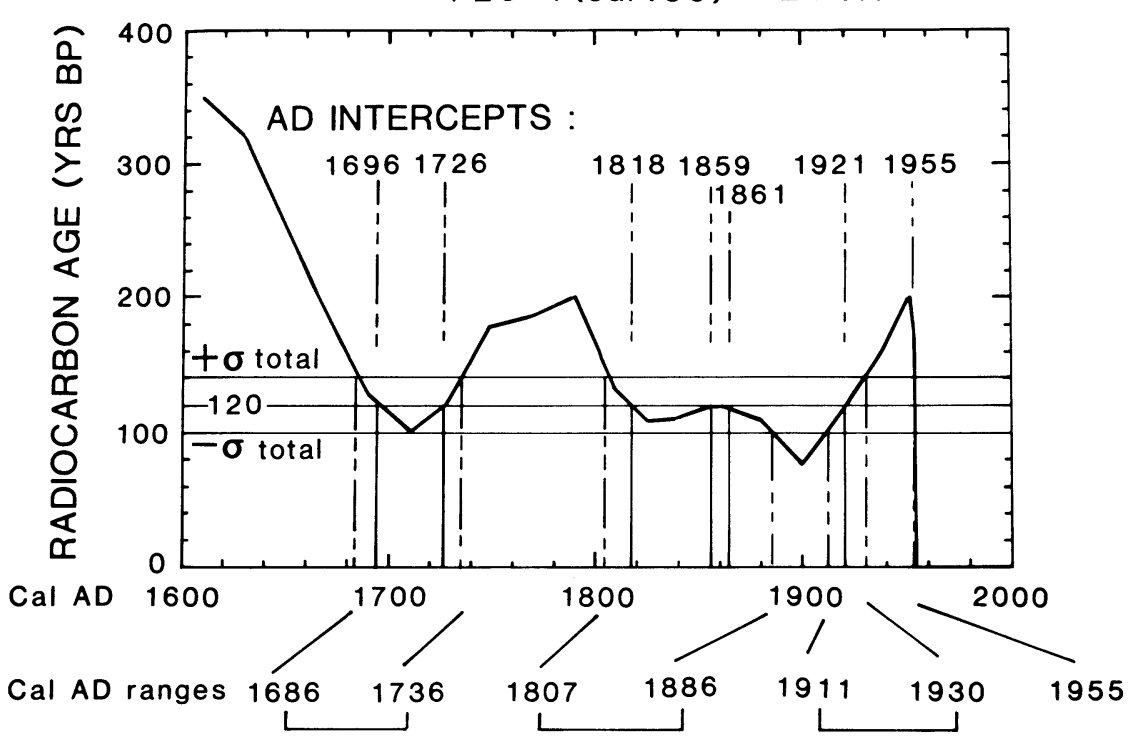

RADIOCARBON AGE BP 2460 CALIBRATED AGES: cal BC 755, 699, 537 Sample $O$ and cal $B C($ cal BP) ranges:

$0=20 \quad 761-682(2710-2631) \quad 659-634(2608-2583) \quad 594-580(2543-2529)$

$0=40 \quad 765-478(2714-2427) \quad 442-420(2391-2369)$

$0=60 \quad 771-408(2720-2357)$

$0=80 \quad 787-405(2736-2354)$

$0=100 \quad 790-400(2740-2350)$

$0=120 \quad 800-400(2750-2350)$

$0=160 \quad 810-390(2760-2340)$

$0=200 \quad 820-380(2770-2330)$

RADIOCARBON AGE BP 2480 CALIBRATED AGES: cal BC 760, 684, 657, 638, 591, 587,551 cal BP $2709,2633,2606,2587,2540$, 2536,2500

Sample $O$ and cal $\mathrm{BC}(\mathrm{cal} \mathrm{BP})$ ranges:

$0=20766-754(2715-2703) \quad 702-535(2651-2484)$

$0=40771-522(2720-2471)$

$0=60 \quad 787-481(2736-2430)$

$0=80 \quad 793-408(2742-2357)$

$0=100 \quad 800-400(2750-2350)$

$0=120 \quad 800-400(2750-2350)$

$0=160 \quad 810-400(2760-2350)$

$0=200 \quad 830-390(2780-2340)$

RADIOCARBON AGE BP 2500 CALIBRATED AGES: cal BC 765, 673, 667, 613, 608 Sample $O$ and cal $B C($ cal $B P)$ ranges:

$0=20 \quad 772-759(2721-2708) \quad 685-655(2634-2604) \quad 641-548(2590-2497)$

$0=40 \quad 787-754(2736-2703) \quad 700-536(2649-2485)$

$0=60 \quad 793-522(2742-2471)$

$0=80 \quad 797-481(2746-2430)$

$0=100 \quad 800-410(2750-2360)$

$440-422(2389-2371)$

$0=120 \quad 810-400(2760-2350)$

$\begin{array}{ll}=160 & 820-400(2770-2350)\end{array}$

RADIOCARBON AGE BP 2520 CALIBRATED AGE: cal BC 770

Sample 0 and cal $\mathrm{BC}$ (cal BP) ranges:

$\begin{array}{lllll}0=20 & 790-764(2739-2713) & 675-665(2624-2614) & 620-604(2569-2553) \\ 0=40 & 793-759(2742-2708) & 685-655(2634-2604) & 640-548(2589-2497) \\ 0=60 & 797-754(2746-2703) & 700-536(2649-2485) & \\ 0=80 & 801-522(2750-2471) & & \\ 0=100 & 810-480(2760-2430) & 440-422(2389-2371) & \\ 0=120 & 810-410(2760-2360) & & \\ 0=160 & 830-400(2780-2350) & & \\ 0=200 & 892-881(2841-2830) & 850-400(2800-2350)\end{array}$


RADIOCARBON AGE BP 2540 CALIBRATED AGE: cal BC 786

Sample 0 and cal $\mathrm{BC}(\mathrm{cal} \mathrm{BP})$ ranges:

$0=20$ 794-769(2743-2718)

$0=40 \quad 797-764(2746-2713) \quad 674-666(2623-2615)$

$0=60 \quad 801-759(2750-2708)$

$0=80 \quad 805-754(2754-2703)$

$0=100 \quad 810-520(2760-2470)$

$0=120 \quad 820-480(2770-2430)$

$0=160 \quad 840-400(2790-2350)$

$0=200 \quad 900-400(2850-2350)$

RADIOCARBON AGE BP 2560 CALIBRATED AGE: cal BC 793

Sample $O$ and cal $B C$ (cal BP) ranges:

$=40-801-769(2750-2718)$

$=60-805-765(2754-2714)$

$=80(809-760(2758-2709)$

$80760(2758-2709)$

$830-520(2780-2470)$

$=160892-882(2841-2831)$

$0=200 \quad 910-400(2860-2350)$ $684-656(2633-2605)$ $700-540(2650-2490)$

$615-607(2564-2556)$ $639-550(2588-2499)$

$850-410(2800-2360)$
$673-667(2622-2616)$

$616-607(2565-2556)$ $639-549(2588-2498)$ $0-536(2649-2485)$

RADIOCARBON AGE BP 2580 CALIBRATED AGE: cal BC 797

Sample $O$ and cal $B C$ (cal BP) ranges

cal BP 2746

$0=20 \quad 802-792(2751-2741)$

$0=40 \quad 805-784(2754-2733)$

$0=60 \quad 809-770(2758-2719)$

$0=80 \quad 819-765(2768-2714)$

$=100 \quad 829-760(2778-2709)$

$0=120 \quad 838-755(2787-2704)$

$0=160 \quad 900-480(2850-2430)$

$0=200 \quad 920-400(2870-2350)$

$67-667(2622-2616)$

$684-656(2633-2605)$

$614-608(2563-2557)$

$439-423(2388-2372)$

$639-550(2588-2499)$

RADIOCARBON AGE BP 2600 CALIBRATED AGE: cal BC 801

Sample $O$ and cal $B C$ (cal BP) ranges

$0=20 \quad 806-796(2755-2745)$

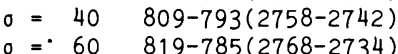

$0=80 \quad 829-770(2778-2719)$

$0=100 \quad 838-765(2787-2714)$

$0=120 \quad 838-765(2787-2714)$

$638-550(2587-2439)$

$910-520(2860-2470)$

$0=200 \quad 976-964(2925-2913)$

$930-410(2880-2360)$

\section{RADIOCARBON AGE BP 2620 CALIBRATED AGE: cal BC 805}

Sample $O$ and cal $\mathrm{BC}(\mathrm{cal} \mathrm{BP})$ ranges

cal BP 2754

$0=20 \quad 810-800(2759-2749)$

$=40 \quad 819-797(2768-2746)$

$0=60 \quad 829-793(2778-2742)$

$0=80 \quad 838-785(2787-2734)$

$0=100 \quad 892-881(2841-2830)$

$848-770(2797-2719)$

$=160 \quad 920-750(2870-2700) \quad 700-540(2650-2490)$

$0=200 \quad 990-480(2940-2430) \quad 439-423(2388-2372)$

$614-608(2563-2557)$

RADIOCARBON AGE BP 2640 CALIBRATED AGE: cal BC 809

Sample $O$ and cal $\mathrm{BC}(\mathrm{cal} \mathrm{BP})$ ranges:

cal BP 2758

$=20 \quad 820-804(2769-2753)$

$=60$ 839-797(2788-2746)

$=80-893-881(2842-2830)$

$=100 \quad 900-790(2850-2740)$

(120 $900-790(2850-2740)$

$=160 \quad 976-964(2925-2913)$

- 160 976-964(2925-2913)

$=200 \quad 1000-520(2950-2470)$

$930-760(2880-2710)$

$684-656(2633-2605)$

RADIOCARBON AGE BP 2660 CALIBRATED AGE: cal BC 818

Cal BP 2767

Sample $O$ and cal $B C$ (cal $B P$ ) ranges:

$0=20 \quad 830-808(2779-2757)$

$0=40 \quad 839-805(2788-2754)$

$0=60 \quad 893-880(2842-2829)$

$0=80 \quad 901-797(2850-2746)$

$0=100 \quad 910-790(2860-2740)$

$\sigma=120 \quad 920-790(2870-2740)$

$0=160 \quad 990-760(2940-2710) \quad 673-667(2622-2616) \quad 614-608(2563-2557)$

$0=200 \quad 1020-750(2970-2700) \quad 700-540(2650-2490)$

RADIOCARBON AGE BP 2680 CALIBRATED AGE: cal BC 828

Sample 0 and cal $\mathrm{BC}(\mathrm{cal} \mathrm{BP})$ ranges:

$0=20 \quad 840-816(2789-2765)$

$0=40 \quad 893-879(2842-2828)$

$0=60 \quad 901-805(2850-2754)$

$0=80 \quad 910-801(2859-2750)$

$0=100 \quad 920-800(2870-2750)$

$=120 \quad 976-964(2925-2913)$

$=200 \quad 1040-760(2990-2710) \quad 684-656(2633-2605)$

$638-550(2587-2499)$ 


\section{RADIOCARBON AGE BP 2700 CALIBRATED AGE: $\begin{array}{lll}\text { cal BC } & 838 \\ \text { cal BP } & 2787\end{array}$}

Sample $O$ and cal $\mathrm{BC}(\mathrm{cal} \mathrm{BP})$ ranges

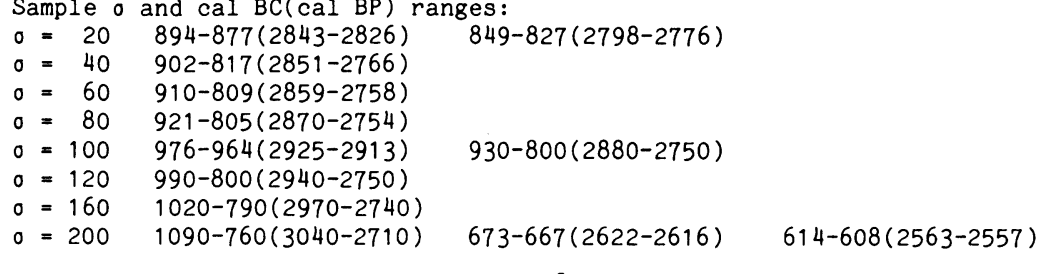

RADIOCARBON AGE BP 2720 CALIBRATED AGES: cal BC 892, 882, 848

Sample $O$ and cal $\mathrm{BC}(\mathrm{cal} \mathrm{BP})$ ranges: cal BP $2841,2831,2797$

$0=20902-836(2851-2785)$

$\begin{array}{ll}0=40 & 910-827(2859-2776) \\ 0=60 & 921-817(2870-2766)\end{array}$

$\begin{array}{ll}0=60 & 921-817(2870-2766) \\ 0=80 & 976-964(2925-2913)\end{array}$

$0=100 \quad 990-800(2940-2750)$

$0=120 \quad 1000-800(2950-2750)$

$0=160 \quad 1050-790(3000-2740)$

$0=200 \quad 1120-770(3070-2720)$

RADIOCARBON AGE BP 2740 CALIBRATED AGE: cal BC 901

Sample $O$ and cal $B C$ (cal $B P$ ) ranges

$0=20 \quad 911-846(2860-2795)$

$0=40 \quad 921-837(2870-2786)$

$0=60 \quad 977-964(2926-2913) \quad 934-828(2883-2777)$

$0=80 \quad 993-818(2942-2767)$

$0=100 \quad 1000-810(2950-2760)$

$\sigma=120 \quad 1020-800(2970-2750)$

$=160 \quad 1090-800(3040-2750)$

$0=200 \quad 1160-790(3110-2740)$

RADIOCARBON AGE BP 2760 CALIBRATED AGE: cal BC 909

Sample $O$ and cal $B C($ cal $B P)$ ranges

$0=20 \quad 922-899(2871-2848)$

$0=40 \quad 977-963(2926-2912) \quad 935-847(2884-2796)$

993-837(2942-2786)

$0=100 \quad 1003-828(2952-2777)$

$0=100 \quad 1020-820(2970-2770)$

$=160 \quad 1120-800(3070-2750)$

$0=200 \quad 1252-1245(3201-3194) \quad 1220-790(3170-2740)$
RADIOCARBON AGE BP 2780 CALIBRATED AGE: cal BC 920

Sample $O$ and cal BC(cal BP) ranges:
$0=20 \quad 979-961(2928-2910) \quad 937-908(2886-2857)$

cal BP 2869

$=40 \quad 993-900(2942-2849)$

$=60 \quad 1004-847(2953-2796)$

$=60 \quad 1004-847(2953-2796)$

$=100 \quad 1050-830(3000-2780)$

- 120 1090-820(3040-2770)

- 160 1160-810(3110-2760)

$0=160 \quad 1160-810(3110-2760)$
$0=200 \quad 1260-800(3210-2750)$

RADIOCARBON AGE BP 2800 CALIBRATED AGES: cal BC 976, 965, 933 Sample $O$ and cal $B C($ cal $B P)$ ranges:

$0=20 \quad 994-919(2943-2868)$

$0=40$
$0=60$
0

$0=60 \quad 1023-900(2972-2849)$

$0=80 \quad 1045-847(2994-2796)$

$0=100 \quad 1090-840(3040-2790)$

$0=120 \quad 1120-830(3070-2780)$

$0=160 \quad 1252-1245(3201-3194) \quad 1220-810(3170-2760)$

$0=200 \quad 1260-800(3210-2750)$

RADIOCARBON AGE BP 2820 CALIBRATED AGE: cal BC 992

Sample $O$ and cal $B C($ cal BP) ranges:

$0=20 \quad 1004-931(2953-2880)$

$0=40 \quad 1023-920(2972-2869)$

$0=60 \quad 1045-909(2994-2858)$

$0=80 \quad 1093-901(3042-2850)$

$0=100 \quad 1120-850(3070-2800)$

$0=120 \quad 1160-840(3110-2790)$

$=160 \quad 1260-820(3210-2770)$

$=200 \quad 1300-810(3250-2760)$

RADIOCARBON AGE BP 2840 CALIBRATED AGE: cal BC 1003

Sample $O$ and cal $\mathrm{BC}(\mathrm{cal} \mathrm{BP})$ ranges:

ca) 2952

$0=20$ 1025-991(2974-2940)

0 - 60 1046-932(29)-2881)

$0=60$ 1093-920 (3042-2869)

$0=80 \quad 1125-909(3074-2858)$

$0=100 \quad 1160-900(3110-2850)$

$1220-850(3170-2800)$

$0=160-1260-830(3210-2780)$ 
RADIOCARBON AGE BP 2860 CALIBRATED AGE: cal BC 102

$0=20 \quad 1047-1002(2996-2951)$

$0=40 \quad 1094-992(3043-2941)$

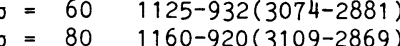

$\sigma=100 \quad 1253-1245(3202-3194) \quad 1220-910(3170-2860)$

$0=120 \quad 1260-900(3210-2850)$

$0=160 \quad 1300-840(3250-2790)$

$0=200 \quad 1382-1341(3331-3290) \quad 1320-820(3270-2770)$

RADIOCARBON AGE BP 2880 CALIBRATED AGE: cal BC 1045

Sample $O$ and cal $\mathrm{BC}(\mathrm{cal} \mathrm{BP})$ ranges:
$0=20 \quad 1095-1016(3044-2965)$

cal

$0=40 \quad 1125-1002(3074-2951)$

$0=60 \quad 1160-992(3109-2941)$

$=60 \quad 1253-1245(3202-3194)$

$1216-932(3165-2881)$

$=100-1260-920(3210-2870)$

$=160-1310-850(3260-2800)$

$0=200 \quad 1390-830(3340-2780)$

RADIOCARBON AGE BP 2900 CALIBRATED AGE: cal BC 1093

RADIOCARBON AGE BP 2900 CALIBRATED AGE: cal BC 1093

Sample $O$ and cal $B C(c a l B P)$ ranges:

$0=20 \quad 1125-1043(3074-2992)$

$0=40 \quad 1160-1020(3109-2969)$

$0=60$ 1252-1245(3201-3194) 1216-1003(3165-2952)

$0=80 \quad 1258-992(3207-2941)$

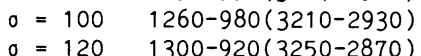

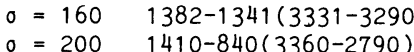

RADIOCARBON AGE BP 2920 CALIBRATED AGES: cal BC 1124, 1113, 1108

Sample $O$ and cal $\mathrm{BC}(\mathrm{cal} \mathrm{BP})$ ranges:

al BP $3073,3062,3057$

$0=20 \quad 1161-1091(3110-3040)$

$0=40 \quad 1253-1245(3202-3194)-1216-1044(3165-2993)$

$0=60 \quad 1258-1020(3207-2969)$

$0=80 \quad 1264-1003(3213-2952)$

$0=100 \quad 1300-990(3250-2940)$

$0=120 \quad 1310-980(3260-2930) \quad 965-933(2914-2882)$

$=160 \quad 1390-910(3340-2860)$

$0=200 \quad 1420-850(3370-2800)$
RADIOCARBON AGE BP 2940 CALIBRATED AGES: Cal BC 1159, 1142, 1138 Sample $O$ and cal $\mathrm{BC}(\mathrm{cal} \mathrm{BP})$ ranges:

cal BP $3108,3091,3087$

$0=20 \quad 1253-1244(3202-3193) \quad 1217-1106(3166-3055)$

$0=40 \quad 1258-1092(3207-3041)$

$0=60 \quad 1264-1044(3213-2993)$

$0=80 \quad 1300-1020(3249-2969)$

$0=100 \quad 1310-1000(3260-2950)$

$0=120 \quad 1382-1341(3331-3290) \quad 1320-990(3270-2940)$

$0=160 \quad 1410-920(3360-2870)$

$0=200 \quad 1420-900(3370-2850)$

RADIOCARBÒN AGE BP 2960 CALIBRATED AGES: cal BC 1252, 1245, 1216 Sample $O$ and cal $B C(c a l B P)$ ranges:

cal BC $1252,1245,1216$

$0=20$ 1259-1157(3208-3106) 1144-1135(3093-3084)

$0=40 \quad 1264-1107(3213-3056)$

$0=60 \quad 1301-1092(3250-3041)$

$0=80 \quad 1357-1350(3306-3299) \quad 1314-1044(3263-2993)$

$0=100 \quad 1382-1340(3331-3289) \quad 1320-1020(3270-2970)$

$=120 \quad 1390-1000(3340-2950)$

$=160 \quad 1420-930(3370-2880)$

$0=1400 \quad 1430-910(3380-2860)$

RADIOCARBON AGE BP 2980 CALIBRATED AGES: cal BC 1258, 1235, 1226

CALIBRATED AGES:
cal BC 1258, 1235, 1226
cal BP 3207, 3184, 3175 Sample $O$ and cal $B C(c a l B P)$ ranges:

$0=20 \quad 1264-1214(3213-3163) \quad 1172-1169(3121-3118)$

$0=40 \quad 1302-1158(3251-3107) \quad 1143-1136(3092-3085)$

$0=60 \quad 1368-1350(3317-3299) \quad 1314-1107(3263-3056)$

$0=80 \quad 1382-1340(3331-3289) \quad 1322-1092(3271-3041)$

$0=100 \quad 1390-1040(3340-2990)$

$0=120 \quad 1410-1020(3360-2970)$

$0=160 \quad 1420-990(3370-2940)$

$0=200 \quad 1450-920(3400-2870)$

RADIOCARBON AGE BP 3000 CALIBRATED AGE: cal BC 1263

Sample 0 and cal BC(cal BP) ranges:

$0=20 \quad 1304-1257(3253-3206) \quad 1237-1224(3186-3173)$

$0=40 \quad 1370-1349(3319-3298) \quad 1315-1215(3264-3164)$

$0=60 \quad 1383-1340(3332-3289) \quad 1322-1159(3271-3108) \quad 1142-1137(3091-3086)$

$0=80 \quad 1395-1107(3344-3056)$

$0=100 \quad 1410-1090(3360-3040)$

$0=120 \quad 1420-1040(3370-2990)$

$=160 \quad 1430-1000(3380-2950)$

$=200 \quad 1507-1475(3456-3424) \quad 1470-980(3420-2930) \quad 965-933(2914-2882)$ 
RADIOCARBON AGE BP 3020 CALIBRATED AGES: cal BC 1300, 1276, 1269

Sample 0 and cal $B C($ cal $B P$ ) ranges:

cal BP $3249,3225,3218$

$0=20$ 1372-1348(3321-3297) 1316-1262(3265-3211)

$0=40 \quad 1383-1340(3332-3289) \quad 1322-1257(3271-3206) \quad 1236-1224(3185-3173)$

$0=60 \quad 1395-1215(3344-3164)$

$0=80 \quad 1407-1159(3356-3108) \quad 1142-1137(3091-3086)$

$0=100 \quad 1420-1110(3370-3060)$

$0=120 \quad 1420-1090(3370-3040)$

$0=160 \quad 1450-1020(3400-2970)$

$0=200 \quad 1510-990(3460-2940)$

\section{RADIOCARBON AGE BP 3040 CALIBRATED AGE: cal BC 1314}

Sample $O$ and cal $\mathrm{BC}(\mathrm{cal} \mathrm{BP})$ ranges:

Sample 0 and $\mathrm{cal}$ BC(cal BP) ranges:
$0=20 \quad 1384-1339(3333-3288) \quad 1323-1295(3272-3244) \quad 1283-1268(3232-3217)$

$\begin{array}{lll}0 & =20 & 1384-1339(3333-3288) \\ 0 & =40 & 1395-1263(3344-3212)\end{array}$

$0=60 \quad 1407-1257(3356-3206) \quad 1236-1225(3185-3174)$

$0=80 \quad 1416-1215(3365-3164)$

$0=100 \quad 1420-1160(3370-3110) \quad 1142-1137(3091-3086)$

$0=120 \quad 1430-1110(3380-3060)$

$0=160 \quad 1510-1040(3460-2990)$

$0=200 \quad 1520-1000(3470-2950)$

RADIOCARBON AGE BP 3060 CALIBRATED AGES: cal BC 1382, 1341, 132 Sample $\sigma$ and cal $\mathrm{BC}(\mathrm{cal} \mathrm{BP})$ ranges:

$0=20 \quad 1397-1312(3346-3261)$

$0=40 \quad 1407-1297(3356-3246) \quad 1280-1268(3229-3217)$

$0=60 \quad 1416-1263(3365-3212)$

$0=80 \quad 1424-1258(3373-3207) \quad 1236-1225(3185-3174)$

$0=100 \quad 1430-1220(3380-3170)$

$0=120 \quad 1450-1160(3400-3110) \quad 1142-1137(3091-3086)$

$0=160 \quad 1510-1090(3460-3040)$

$0=200 \quad 1520-1020(3470-2970)$

RADIOCARBON AGE BP 3080 CALIBRATED AGES: cal BC 1394, 1331, 1329

Sample 0 and cal $\mathrm{BC}(\mathrm{cal} \mathrm{BP})$ ranges:

$0=20 \quad 1408-1379(3357-3328) \quad 1343-1320(3292-3269)$

$0=40 \quad 1416-1313(3365-3262)$

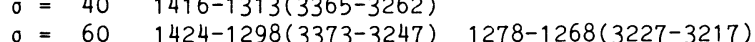

$0=60 \quad 1424-1298(3373-3247)$

$0=80 \quad 1434-1263(3383-3212) \quad 1258-1225(3184-3174)$

$0=120 \quad 1510-1220(3460-3170)$

$0=160$ 1520-1120(3470-3070) 1113-1108(3062-3057)

$0=160$
$0=200$
0
RADIOCARBON AGE BP 3100 CALIBRATED AGE: cal BC 1406

Sample $O$ and cal $\mathrm{BC}(\mathrm{cal} \mathrm{BP})$ ranges:

cal BP 3355

$0=20$ 1417-1392(3366-3341) 1333-1328(3282-3277)

$0=40 \quad 1425-1381(3374-3330) \quad 1342-1321(3291-3270)$

$0=60 \quad 1434-1313(3383-3262)$

$0=80 \quad 1445-1299(3394-3248) \quad 1278-1269(3227-3218)$

$0=100 \quad 1510-1260(3460-3210)$

$0=120 \quad 1510-1260(3460-3210) \quad 1235-1225(3184-3174)$

$0=160 \quad 1520-1160(3470-3110) \quad 1142-1137(3091-3086)$

$0=200 \quad 1607-1554(3556-3503) \quad 1540-1090(3490-3040)$

RADIOCARBON AGE BP 3120 CALIBRATED AGE: cal BC 1416

Sample $O$ and cal $\mathrm{BC}(\mathrm{cal} \mathrm{BP})$ ranges:

$0=20 \quad 1425-1404(3374-3353)$

$1332-1328(3281-3277)$

1446-1381(3395-3330) 1341-1321(3290-3270)

$0=80 \quad 1508-1314(3457-3263)$

$0=100 \quad 1510-1300(3460-3250) \quad 1277-1269(3226-3218)$

$=120$ 1520-1260(3470-3210)

$0=160 \quad 1591-1570(3540-3519) \quad 1530-1220(3480-3170)$

$0=200 \quad 1620-1120(3570-3070) \quad 1113-1108(3062-3057)$

RADIOCARBON AGE BP 3140 CALIBRATED AGE: cal BC 1424

Sample $O$ and cal $\mathrm{BC}(\mathrm{cal} \mathrm{BP})$ ranges:

$0=20 \quad 1435-1414(3384-3363)$

$0=40 \quad 1446-1405(3395-3354)$

$0=60 \quad 1508-1393(3457-3342) \quad 1332-1329(3281-3278)$

$0=80 \quad 1514-1381(3463-3330) \quad 1341-1321(3290-3270)$

$0=100 \quad 1520-1310(3470-3260)$

$0=120 \quad 1520-1300(3470-3250) \quad 1277-1269(3226-3218)$

$0=160 \quad 1610-1260(3560-3210) \quad 1235-1225(3184-3174)$

$0=200 \quad 1640-1160(3590-3110) \quad 1142-1138(3091-3087)$

RADIOCARBON AGE BP 3160 CALIBRATED AGE: cal BC 1433

Sample 0 and cal $\mathrm{BC}(\mathrm{cal} \mathrm{BP})$ ranges:

$0=20 \quad 1446-1423(3395-3372)$

$0=40 \quad 1508-1415(3457-3364)$

$0=60 \quad 1514-1405(3463-3354)$

$0=80 \quad 1519-1394(3468-3343) \quad 1332-1329(3281-3278)$

$0=100 \quad 1520-1380(3470-3330) \quad 1341-1321(3290-3270)$

$0=120 \quad 1591-1570(3540-3519) \quad 1530-1310(3480-3260)$

$0=160 \quad 1620-1260(3570-3210)$

$0=200 \quad 1680-1220(3630-3170)$ 
RADIOCARBON AGE BP 3180 CALIBRATED AGE: cal BC 1445

Sample $O$ and cal $\mathrm{BC}(\mathrm{cal} \mathrm{BP})$ ranges:

cal BP 3394

$0=20 \quad 1510-1432(3459-3381)$

$0=40 \quad 1514-1423(3463-3372)$

$0=60 \quad 1519-1415(3468-3364)$

$0=80 \quad 1523-1406(3472-3355)$

$0=100 \quad 1591-1570(3540-3519) \quad 1530-1390(3480-3340) \quad 1332-1329(3281-3278)$

$0=120 \quad 1610-1380(3560-3330) \quad 1341-1321(3290-3270)$

$0=160 \quad 1640-1300(3590-3250) \quad 1277-1269(3226-3218)$

$0=200 \quad 1690-1260(3640-3210) \quad 1235-1225(3184-3174)$

RADIOCARBON AGE BP 3200 CALIBRATED AGES: cal BC 1506, 1476, 1464

Sample $O$ and cal $B C($ cal $B P$ ) ranges:

cal BP 3455 , 342

$\begin{array}{rl}0 & =20 \\ 0 & 1515-1443(3464-3392)\end{array}$

$0=60 \quad 1524-1423(3473-3372)$

$0=80 \quad 1591-1570(3540-3519) \quad 1528-1415(3477-3364)$

$0=100 \quad 1610-1410(3560-3360)$

$0=120 \quad 1620-1390(3570-3340) \quad 1332-1329(3281-3278)$

$1680-1310(3630-3260)$

$0=200 \quad 1734-1721(3683-3670) \quad 1700-1260(3650-3210)$

RADIOCARBON AGE BP 3220 CALIBRATED AGE: cal BC 1514

Sample $O$ and cal $B C$ (cal $B P$ ) ranges:

cal BP 3463

$0=20 \quad 1520-1500(3469-3449) \quad 1481-1459(3430-3408)$

$0=40-1524-1444(3473-3393)$

$0=60 \quad 1591-1569(3540-3518) \quad 1528-1432(3477-3381)$

$0=80 \quad 1607-1423(3556-3372)$

$0=100 \quad 1620-1420(3570-3370)$

$0=120 \quad 1640-1410(3590-3360)$

$0=160 \quad 1690-1380(3640-3330) \quad 1341-1321(3290-3270)$

$0=200 \quad 1740-1300(3690-3250) \quad 1277-1269(3226-3218)$

RADIOCARBON AGE BP 3240 CALIBRATED AGE: $\begin{array}{lll}\text { cal BC } 1519 \\ \text { cal BP } 3468\end{array}$

Sample o and cal $\mathrm{BC}(\mathrm{cal} \mathrm{BP})$ ranges:

$0=20 \quad 1524-1513(3473-3462)$

$0=40 \quad 1592-1569(3541-3518) \quad 1528-1503(3477-3452) \quad 1478-1462(3427-3411)$

$0=60 \quad 1608-1444(3557-3393)$

$0=80 \quad 1622-1433(3571-3382)$

$0=100 \quad 1640-1420(3590-3370)$

$0=120 \quad 1680-1420(3630-3370)$

$0=160 \quad 1734-1721(3683-3670)$

$0=200 \quad 1750-1310(3700-3260)$
RADIOCARBON AGE BP 3260 CALIBRATED AGE: $\begin{aligned} & \text { cal BC } 1523 \\ & \text { cal BP } 3472\end{aligned}$

Sample 0 and cal $\mathrm{BC}(\mathrm{cal} \mathrm{BP})$ ranges:

$0=20$ 1593-1567(3542-3516) 1529-1518(3478-3467)

$0=40 \quad 1608-1514(3557-3463)$

$0=60 \quad 1622-1504(3571-3453) \quad 1477-1463(3426-3412)$

$0=80 \quad 1644-1444(3593-3393)$

$0=100 \quad 1680-1430(3630-3380)$

$0=120 \quad 1690-1420(3640-3370)$

$0=160 \quad 1740-1410(3690-3360)$

$0=200 \quad 1852-1850(3801-3799) \quad 1760-1380(3710-3330) \quad 1341-1321(3290-3270)$

RADIOCARBON AGE BP 3280 CALIBRATED AGES: cal BC 1590, 1579, 1528

Sample $O$ and cal $\mathrm{BC}(\mathrm{cal} \mathrm{BP})$ ranges:

$\begin{array}{ll}0=20 & 1610-1522(3559-3471) \\ 0=40 & 1623-1518(3572-3467)\end{array}$

$0=60 \quad 1645-1514(3594-3463)$

$=80 \quad 1678-1505(3627-3454)$

$=100 \quad 1690-1440(3640-3390)$

$=160 \quad 1750-1420(3700-3370)$

$0=200 \quad 1872-1842(3821-3791) \quad 1813-1806(3762-3755) \quad 1780-1390(3730-3340)$ $1331-1329(3280-3278)$

RADIOCARBON AGE BP 3300 CALIBRATED AGES: cal BC $1607,1554,1543$

Sample $O$ and cal $\mathrm{BC}(\mathrm{cal} \mathrm{BP})$ ranges:

$0=20 \quad 1624-1527(3573-3476)$

$0=40 \quad 1670-1665(3619-3614) \quad 1646-1523(3595-3472)$

$0=60 \quad 1678-1518(3627-3467)$

$0=80 \quad 1685-1514(3634-3463)$

$0=100 \quad 1734-1721(3683-3670) \quad 1700-1500(3650-3450) \quad 1477-1463(3426-3412)$

$0=120 \quad 1740-1440(3690-3390)$

$0=160 \quad 1852-1849(3801-3798) \quad 1760-1420(3710-3370)$

$0=200 \quad 1880-1410(3830-3360)$

RADIOCARBON AGE BP 3320 CALIBRATED AGE: cal BC 1621

Sample 0 and cal $\mathrm{BC}(\mathrm{cal} \mathrm{BP})$ ranges:

cal BP 3570

$0=20 \quad 1671-1604(3620-3553) \quad 1557-1540(3506-3489)$

$0=40 \quad 1678-1528(3627-3477)$

$0=60 \quad 1685-1523(3634-3472)$

$0=80 \quad 1734-1721(3683-3670) \quad 1698-1518(3647-3467)$

$0=100 \quad 1740-1510(3690-3460)$

$0=120 \quad 1750-1510(3700-3460) \quad 1476-1464(3425-3413)$

$0=160 \quad 1872-1842(3821-3791)$ $0=200 \quad 1880-1420(3830-3370)$ 
TABLE 2-L

RADIOCARBON AGE BP 3340 CALIBRATED AGE: cal BC 1643

Sample $O$ and cal $B C(c a l B P)$ ranges:

$0=20 \quad 1678-1619(3627-3568)$

$0=40 \quad 1686-1605(3635-3554) \quad 1556-1542(3505-3491)$

$0=60 \quad 1734-1721(3683-3670) \quad 1698-1528(3647-3477)$

$0=80 \quad 1740-1523(3689-3472)$

$0=100 \quad 1750-1520(3700-3470)$

$0=120 \quad 1852-1850(3801-3799) \quad 1760-1510(3710-3460)$

$0=160 \quad 1880-1440(3830-3390)$

$0=200 \quad 1890-1420(3840-3370)$

RADIOCARBON AGE BP 3360 CALIBRATED AGE: $\begin{array}{lll}\text { cal BC } & 1677 \\ \text { cal BP } & 3626\end{array}$

Sample 0 and cal $B C$ (cal BP) ranges:

$0=20 \quad 1686-1636(3635-3585)$

$=40 \quad 1734-1720(3683-3669) \quad 1699-1620(3648-3569)$

$0=60 \quad 1740-1605(3689-3554)$

$0=80 \quad 1747-1528(3696-3477)$

$0=120 \quad 1872-1842(3821-3791) \quad 1813-1806(3762-3755)$

1880-1510(3830-3460) 1476-1464(3425-3413)

$=200 \quad 1910-1430(3860-3380)$

RADIOCARBON AGE BP 3380 CALIBRATED AGE: cal BC 1685

Sample $O$ and cal $B C($ cal BP) ranges:

$0=20 \quad 1735-1718(3684-3667) \quad 1700-1676(3649-3625)$

$=40 \quad 1747-1620(3696-3569)$

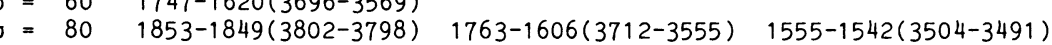

$=100 \quad 1872-1842(3821-3791) \quad 1813-1806(3762-3755) \quad 1780-1530(3730-3480)$

$=120 \quad 1880-1520(3830-3470)$

$=160 \quad 1890-1510(3840-3460)$

$0=200 \quad 1940-1440(3890-3390)$

RADIOCARBON AGE BP 3400 CALIBRATED AGES: cal BC 1733, 1721, 1697

Sample 0 and cal $\mathrm{BC}(\mathrm{cal} \mathrm{BP})$ ranges:

cal BP $3682,3670,3646$

$0=20 \quad 1741-1683(3690-3632)$

$0=40 \quad 1747-1676(3696-3625)$

$0=60 \quad 1853-1849(3802-3798) \quad 1763-1640(3712-3589)$

$0=80 \quad 1872-1842(3821-3791) \quad 1813-1806(3762-3755) \quad 1778-1620(3727-3569)$

$0=100 \quad 1880-1610(3830-3560) \quad 1555-1542(3504-3491)$

$0=120 \quad 1880-1530(3830-3480)$

$0=160 \quad 1910-1520(3860-3470)$

$0=200 \quad 1960-1510(3910-3460) \quad 1476-1464(3425-3413)$
TABIE 2-M

RADIOCARBON AGE BP 3420 CALIBRATED AGE: CaI BC 1740

Sample $O$ and cal $\mathrm{BC}(\mathrm{cal} \mathrm{BP})$ ranges

$0=20 \quad 1747-1693(3696-3642)$

$0=40$ 1854-184(3803-3798) $1764-1684(3713-3633)$

$0=60 \quad 1872-1841(3821-3790) \quad 1813-1806(3762-3755) \quad 1778-1677(3727-3626)$

$0=80 \quad 1878-1641(3827-3590)$

$0=100 \quad 1880-1620(3830-3570)$

$0=120 \quad 1890-1610(3840-3560) \quad 1555-1543(3504-3492)$

$0=160 \quad 1940-1520(3890-3470)$

$0=200 \quad 2019-2002(3968-3951) \quad 1980-1510(3930-3460)$

RADIOCARBON AGE BP 3440 CALIBRATED AGE: $\begin{aligned} & \text { cal BC } 1746 \\ & \text { cal BP } 3695\end{aligned}$

Sample $O$ and cal $\mathrm{BC}(\mathrm{cal} \mathrm{BP})$ ranges :

$0=20$ 1856-1848(3805-3797) 1766-1739(3715-3688)

$0=40 \quad 1872-1841(3821-3790) \quad 1814-1805(3763-3754) \quad 1778-1695(3727-3644)$

$0=60 \quad 1878-1685(3827-3634)$

$0=80 \quad 1883-1677(3832-3626)$

$0=100 \quad 1890-1640(3840-3590)$

$0=120 \quad 1910-1620(3860-3570)$

$0=160 \quad 1960-1530(3910-3480)$

$0=200 \quad 2030-1520(3980-3470)$

RADIOCARBON AGE BP 3460 CALIBRATED AGES: cal BC 1851, 1850, 1761

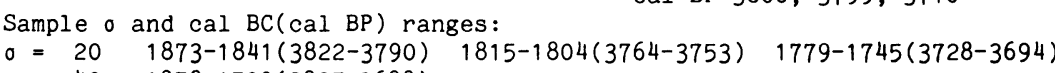

$\begin{array}{rl}0 & =20 \\ 0 & 1873-1841(3822-3790)\end{array}$

$0=601883-1733(3832-3682) \quad 1722-1696(3671-3645)$

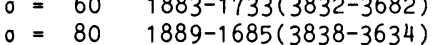

$=100$ 1910-1680(3860-3630)

$0=100 \quad 1910-1680(3860-3630)$

$\begin{aligned} & 0=160 \quad 2019-2002(3968-3951) \\ & 0=200\end{aligned} \quad 1980-1610(3930-3560) \quad 1555-1543(3504-3492)$

$200 \quad 2040-1520(3990-3470)$

RADIOCARBON AGE BP 3480 CALIBRATED AGES: cal BC 1872, 1842, 1813, 1807, 1777 Sample $O$ and cal $\mathrm{BC}(\mathrm{cal} \mathrm{BP})$ ranges:

cal BP $3821,3791,3762,3756,3726$

$0=20$ 1878-1757(3827-3706)

$0=40 \quad 1883-1746(3832-3695)$

$0=601889-1739(3838-3688)$

$0=80 \quad 1909-1733(3858-3682) \quad 1722-1696(3671-3645)$

$0=100 \quad 1940-1680(3890-3630)$

$0=120 \quad 1960-1680(3910-3630)$

$0=160 \quad 2030-1620(3980-3570)$

$0=200 \quad 2123-2080(4072-4029) \quad 2040-1530(3990-3480)$ 
RADIOCARBON AGE BP 3500 CALIBRATED AGES: cal BC 1877, 1834, 1824, 1793, 1788 Sample $O$ and cal $\mathrm{BC}(\mathrm{cal} \mathrm{BP})$ ranges:

cal BP $3826,3783,3773,3742,37$

$0=20 \quad 1884-1871(3833-3820) \quad 1843-1775(3792-3724)$

$0=40 \quad 1889-1759(3838-3708)$

$0=60 \quad 1909-1746(3858-3695)$

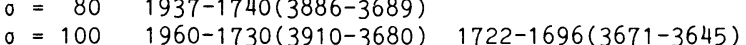

$0=100 \quad 1960-1730(3910-3680)-1722-1696(3671-3645)$

$0=160 \quad 2040-1640(3990-3590)$

$0=200 \quad 2133-2066(4082-4015) \quad 2050-1610(4000-3560) \quad 1555-1543(3504-3492)$

RADIOCARBON AGE BP 3520 CALIBRATED AGE: cal BC 1883

Sample $O$ and cal $B C($ cal BP) ranges:

1835-1822(3784-3771) 1795-1786(3744-3735)

$0=40 \quad 1910-1871(3859-3820) \quad 1843-1776(3792-3725)$

$=60 \quad 1938-1760(3887-3709)$

$0=80 \quad 1962-1746(3911-3695)$

$0=100 \quad 2019-2002(3968-3951) \quad 1980-1740(3930-3690)$

$0=120 \quad 2030-1730(3980-3680) \quad 1722-1696(3671-3645)$

$0=160 \quad 2123-2080(4072-4029) \quad 2040-1680(3990-3630)$

$0=200 \quad 2140-1620(4090-3570)$

RADIOCARBON AGE BP 3540 CALIBRATED AGE: cal BC 1888

Sample $O$ and cal $B C($ cal $B P)$ ranges:

cal BP 3837

$0=20 \quad 1913-1882(3862-3831)$

$0=40 \quad 1938-1877(3887-3826) \quad 1835-1823(3784-3772) \quad 1794-1787(3743-3736)$

$0=60 \quad 1963-1872(3912-3821) \quad 1842-1776(3791-3725)$

$0=80 \quad 2019-2001(3968-3950) \quad 1980-1760(3929-3709)$

$0=100 \quad 2030-1750(3980-3700)$

$0=120 \quad 2040-1740(3990-3690)$

$=160 \quad 2133-2066(4082-4015) \quad 2050-1680(4000-3630)$

$0=200 \quad 2182-2166(4131-4115) \quad 2140-1640(4090-3590)$

RADIOCARBON AGE BP 3560 CALIBRATED AGE: cal BC 1908

Sample $O$ and cal $\mathrm{BC}(\mathrm{cal} \mathrm{BP})$ ranges:

$0=40 \quad 1941-1887(3890-3836)$

$0=60 \quad 2019-2001(3968-3950) \quad 1981-1877(3930-3826) \quad 1835-1823(3784-3772)$ $794-1787(3743-3736)$

$=802032-1872(3981-3821)$

$0=100 \quad 2040-1760(3990-3710)$

$=120$ 2123-2080(4072-4029) 2040-1750(3990-3700)

$=1602140-1730(4090-3680) \quad 1722-1696(3671-3645)$

$=200 \quad 2190-1680(4140-3630)$
RADIOCARBON AGE BP 3580 CALIBRATED AGE: cal BC 1936

Sample 0 and cal $\mathrm{BC}(\mathrm{cal} \mathrm{BP})$ ranges :

$0=20 \quad 1966-1904(3915-3853)$

$0=40 \quad 2020-2001(3969-3950) \quad 1981-1888(3930-3837)$

$0=60 \quad 2032-1882(3981-3831)$

0 80 2037-1877(3986-3826) 1835-1823(3784-3772)

$1794-1787(3743-3736)$

1842-1777(3791-3726)

$0=120 \quad 2133-2066(4082-4015) \quad 2050-1760(4000-3710)$

$2182-2166(4131-4115) \quad 2140-1740(4090-3690)$

$0=200 \quad 2200-1680(4150-3630)$

RADIOCARBON AGE BP 3600 CALIBRATED AGE: cal BC 1961

cal BP 3910

Sample 0 and cal $\mathrm{BC}(\mathrm{cal} \mathrm{BP})$ ranges:

$0=20 \quad 2022-1999(3971-3948) \quad 1982-1932(3931-3881)$

$0=40 \quad 2032-1905(3981-3854)$

$0=\begin{array}{lll}80 & 2124-2079(4073-4028) & 2042-1883(3991-3832\end{array}$

$0=100 \quad 2133-2065(4082-4014) \quad 2050-1880(4000-3830)$ $1794-1787(3743-3736)$

$=120 \quad 2140-1870(4090-3820) \quad 1842-1777(3791-3726)$

$0=160 \quad 2200-1750(4150-3700)$

$0=200 \quad 2278-2233(4227-4182) \quad 2210-1730(4160-3680) \quad 1722-1696(3671-3645)$

RADIOCARBON AGE BP 3620 CALIBRATED AGES: cal BC 2018, 2002, 1980

Sample 0 and cal $\mathrm{BC}(\mathrm{cal} \mathrm{BP})$ ranges:

cal BP $3967,3951,3929$

$0=20 \quad 2033-1954(3982-3903)$

$0=40 \quad 2037-1934(3986-3883)$

$0=60 \quad 2124-2079(4073-4028) \quad 2042-1906(3991-3855)$

$0=80 \quad 2133-2065(4082-4014) \quad 2047-1888(3996-3837)$

$0=100 \quad 2140-1880(4090-3830)$

$0=120 \quad 2183-2166(4132-4115) \quad 2140-1880(4090-3830) \quad 1834-1824(3783-3773)$

$1794-1787(3743-3736)$

$=160 \quad 2200-1760(4150-3710)$

$0=200 \quad 2290-1740(4240-3690)$

RADIOCARBON AGE BP 3640 CALIBRATED AGE: cal BC 2032

$=20 \quad 2096-2089(4045-4038) \quad 2038-2015(3987-3964) \quad 2005-1977(3954-3926)$

$0=40 \quad 2125-2079(4074-4028) \quad 2042-1958(3991-3907)$

$60-2133-2065(4082-4014) \quad 2047-1935(3996-3884)$

$0=80$ (2138-1907(4087-3856)

$0=100 \quad 2182-2166(4131-4115) \quad 2140-1890(4090-3840)$

$0=120 \quad 2200-1880(4150-3830)$

$0=1602278-2233(4227-4182) \quad 2210-1870(4160-3820) \quad 1842-1777(3791-3726)$

$0=200 \quad 2320-1750(4270-3700)$ 
TABLE 2-P

RADIOCARBON AGE BP 3660 CALIBRATED AGE: cal BC 2037

Sample $O$ and $\mathrm{Cal} \mathrm{BC}(\mathrm{cal} \mathrm{BP})$ ranges:

= 2126-2078(4075-4027) 2043-2031(3992-3980)

2004-1978(3953-3927)

$0=40 \quad 2133-2064(4082-4013)$

$0=60 \quad 2138-1959(4087-3908) 2142-1935(4091-3884)$

$0=80 \quad 2183-2166(4132-415)$

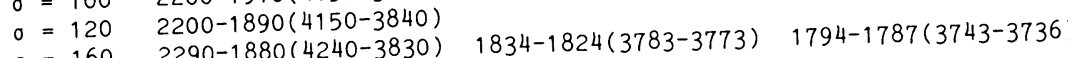

$=200 \quad 2340-1760(4290-3710)$

RADIOCARBON AGE BP 3680 CALIBRATED AGES: $\begin{aligned} & \text { cal BC 2123, 2080, } 2042 \\ & \text { cal BP 4072, 4029, } 3991\end{aligned}$

Sample 0 and cal BC(cal BP) ranges:
$02134-2061(4083-4010)$
$2048-2036(3997-3985)$

$0=402138-2031(4087-3980)$

$0=60 \quad 2183-2165(4132-4114)$

$0=80 \quad 2195-1959(4144-3908)$

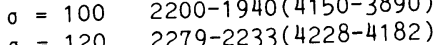

$0=120 \quad 2279-2233(4228-4182)$

$0=200$ $2320-1880(4270-3830)$

RADIOCARBON AGE BP 3700 CALIBRATED AGES: cal BC 2133, 2067, 2047

Sample 0 and cal $\mathrm{BC}(\mathrm{cal} \mathrm{BP})$ ranges:

Sample and cal BC(cal B $082-2041(4031-3990)$

$0=20 \quad 2138-2119(4087-4068) \quad 2082-2041(4031-3990)$

$0=40-2184-2165(4133-4114)$

$0=\begin{array}{ll}60 & 2195-2031(4144-3980) \\ 8 & 2003-1979(3952-3928)\end{array}$

$0=80 \quad 2202-2017(4151-3966) \quad 2003-1979(3952-3928)$

$\begin{aligned} & 0=100 \\ & 0=120 \\ & 0\end{aligned} 2290-1940(4240-3890)$

$0=160 \quad 2340-1890(4290-3840)$

$0=200 \quad 2460-1880(4410-3830) \quad 1834-1824(3783-3773) \quad 1793-1787(3742-3736)$

RADIOCARBON AGE BP 3720 CALIBRATED AGE: $\begin{array}{lll}\text { cal BC } 2138 \\ \text { cal BP } 4087\end{array}$

Sample $O$ and cal $B C($ cal BP) ranges:

$0=20 \quad 2186-2164(4135-4113) \quad 2143-2132(4092-4081)$

$=40 \quad 2195-2121(4144-4070)$

$0=602209-2031(4158-3980)$

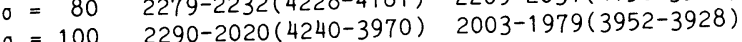

$0=120 \quad 2320-1960(4270-3910)$

$\begin{array}{ll}0 & =160 \\ 0 & 2453-2423(4402-4372) \\ 0 & 2400-1910(4350-3860)\end{array}$

$0=160 \quad 2450-1880(4410-3830)$
RADIOCARBON AGE BP 3740 CALIBRATED AGES: cal BC 2181, 2166, 2142

Sample $O$ and cal $\mathrm{BC}(\mathrm{cal} \mathrm{BP})$ ranges

$0=20 \quad 2196-2137(4145-4086)$

$2069-2047(4018-3996)$

2081-2042(4030-3991)

$=80 \quad 2289-2037(4238-3986)$

$0=100 \quad 2320-2030(4270-3980)$

$0=120 \quad 2340-2020(4290-3970) \quad 2003-1979(3952-3928)$

$0=160 \quad 2460-1940(4410-3890)$

$0=200 \quad 2470-1890(4420-3840)$

RADIOCARBON AGE BP 3760 CALIBRATED AGES: cal BC 2195, 2156, 2147

Sample $O$ and cal $B C($ cal $B P)$ ranges:

$=20 \quad 2203-2142(4152-4091)$

$=40 \quad 2279-2232(4228-4181) \quad 2209-2137(4158-4086)$

$0=602289-2133(4238-4082) \quad 2068-2047(4017-3996)$

$0=80$ 2317-2122(4266-4071) 2081-2042(4030-3991)

$=100 \quad 2340-2040(4290-3990)$

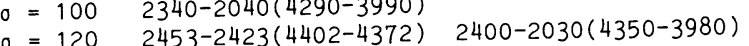

$=160 \quad 2460-1960(4410-3910)$

o $2470-1910(4420-3860)$

RADIOCARBON AGE BP 3780 CALIBRATED AGE: cal BC 2202

cal BP 415

Sample $O$ and cal BC(cal BP) ranges:

$\sigma=20 \quad 2279-2231(4228-4180) 2210-2194(4159-4143)$

$0=40 \quad 2289-2180(4238-4129) \quad 2167-2142(4116-4091)$

$0=60 \quad 2318-2137(4267-4086) \quad 2068-2047(4017-3996)$

$0=80 \quad 2344-2133(4293-4082) \quad 2068-2047(4017-3996) \quad 2080-2042(4029-3991)$

$0=100 \quad 2453-2423(4402-4372)$

$\begin{array}{lll}= & 160 & 2470-2020(4420-3970) \\ 0 & 2002-1980(3951-3929)\end{array}$

$0=200>2490-1940(>4440-3890)$

RADIOCARBON AGE BP 3800 CALIBRATED AGES: cal BC 2278, 2233, 2209

Sample $O$ and cal $\mathrm{BC}(\mathrm{cal} \mathrm{BP})$ ranges:
$0=20 \quad 2290-2201(4239-4150)$ al $B P 4227,4182,4158$

$0=40 \quad 2320-2194(4269-4143) \quad 2157-2146(4106-4095)$

$0=60 \quad 2344-2180(4293-4129) \quad 2167-2142(4116-4091)$

$0=80 \quad 2453-2423(4402-4372) \quad 2399-2137(4348-4086)$

$0=100 \quad 2460-2130(4410-4080) \quad 2068-2047(4017-3996)$

$0=120 \quad 2460-2120(4410-4070) \quad 2080-2042(4029-3991)$

$0=160 \quad 2470-2030(4420-3980)$

$=200>2490-1960(>4440-3910)$ 


\section{TABLE 2-R}

RADIOCARBON AGE BP 3820

CALIBRATED AGE :

cal BC 2288

Sample 0 and cal $B C($ cal $B P)$ ranges:

cal BP 4237

$0=20 \quad 2325-2276(4274-4225) \quad 2238-2207(4187-4156)$

$0=40 \quad 2345-2201(4294-4150)$

$0=60 \quad 2453-2422(4402-4371) \quad 2399-2194(4348-4143)$

$0=80 \quad 2458-2180(4407-4129) \quad 2167-2142(4116-4091)$

o $=100(2460-2140(4410-4090)$

$0=120 \quad 2470-2130(4420-4080) \quad 2068-2047(4017-3996)$
$0=160 \quad>2490-2040(>4440-3990)$

$0=200 \quad>2490-2020(>4440-3970) \quad 2003-1979(3952-3928)$

RADIOCARBON AGE BP 3840 CALIBRATED AGE: cal BC 2316

Sample $O$ and cal BC(cal BP) ranges:

cal BP 4265

$0=20 \quad 2347-2286(4296-4235)$

$0=\begin{array}{llll}40 & 2454-2422(4403-4371) & 2400-2277(4349-4226) & 2236-2208(4185-4157)\end{array}$

$0=60 \quad 2458-2201(4407-4150)$

$0=80 \quad 2462-2194(4411-4143) \quad 2157-2147(4106-4096)$

$0=100 \quad 2470-2180(4420-4130) \quad 2166-2142(4115-4091)$

$0=120 \quad 2470-2140(4420-4090)$

$0=160 \quad>2490-2120(>4440-4070) \quad 2080-2042(4029-3991)$

$0=200>2490-2030(>4440-3980)$

\section{RADIOCARBON AGE BP 3860 CALIBRATED AGE: Cal BC 2343}

Sample $O$ and cal $\mathrm{BC}(\mathrm{cal} \mathrm{BP})$ ranges:

$\begin{array}{lll}\text { cal } & \text { BC } 2343 \\ \text { cal } & \text { BP } & 4292\end{array}$

$0=20 \quad 2454-2421(4403-4370) 2401-2309(4350-4258)$

$=\begin{array}{lll}60 & 2462-2278(4411-4227) \quad 2235-2208(4184-4157)\end{array}$

$0=80 \quad 2466-2201(4415-4150)$

$0=100 \quad 2470-2190(4420-4140) \quad 2157-2147(4106-4096)$

$=120 \quad>2490-2180(>4440-4130) \quad 2166-2142(4115-4091)$

$=160 \quad>2490-2130(>4440-4080) \quad 2067-2047(4016-3996)$

RADIOCARBON AGE BP 3880 CALIBRATED AGES: cal BC 2453, 2423, 2398

Sample $O$ and cal $\mathrm{BC}(\mathrm{cal} \mathrm{BP})$ ranges

cal BP $4402,4372,4347$

$0=20 \quad 2458-2340(4407-4289)$

$0=40 \quad 2462-2311(4411-4260)$

$0=60 \quad 2466-2288(4415-4237)$

$0=80$ 2471-2278(4420-4227) 2234-2208(4183-4157)

$0=100 \quad>2490-2200(>4440-4150)$

$0=120>2490-2190(>4440-4140) \quad 2157-2147(4106-4096)$

$0=160 \quad>2490-2140(>4440-4090)$
$0=200 \quad>2490-2120(>4440-4070) \quad 2080-2042(4029-3991)$
TABLE 2-S

RADIOCARBON AGE BP 3900 CALIBRATED AGE: cal BC 2457

Sample $O$ and cal $B C($ cal $B P)$ ranges:

$0=20 \quad 2462-2452(4411-4401) 2426-2396(4375-4345)$

$=40 \quad 2466-2342(4415-4291)$

$0=80>2490-2288(>4439-4237)$

$0=100>2490-2280(>4440-4230)$

$0=120>2490-2200(>4440-4150) \quad 2234-2209(4183-4158)$

$0=160>2490-2180(>4440-4130)$

$0=200>2490-2130(>4440-4080) \quad 2166-2142(4115-4091)$

$>2490-2130(>4440-4080) \quad 2067-2047(4016-3996)$

RADIOCARBON AGE BP 3920 CALIBRATED AGE: cal BC 2462

Sample $O$ and cal $B C$ (cal BP) ranges:

cal BP 4411

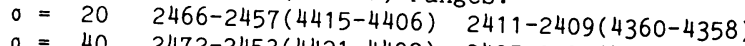

$0=40 \quad 2472-2453(4421-4402) \quad 2425-2397(4374-4346)$

$0=80 \quad>2490-2342(>4439-4291)$

$0=800>2490-2314(>4439-4263)$

$0=100>2490-2290(>4440-4240)$

$0=120 \quad>2490-2280(>4440-4230) \quad 2234-2209(4183-4158)$

$0=160 \quad>2490-2190(>4440-4140) \quad 2157-2147(4106-4096)$

$0=200>2490-2140(>4440-4090)$

RADIOCARBON AGE BP 3940 CALIBRATED AGE: Cal BC 2466

Sample $O$ and cal $\mathrm{BC}(\mathrm{cal} \mathrm{BP})$ ranges:

$0=20 \quad 2474-2461(4423-4410)$

$0=40 \quad>2490-2457(>4439-4406)$

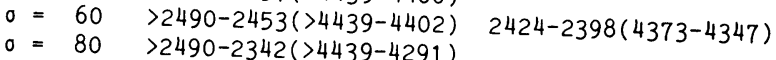

$0=100 \quad>2490-2310(>4440-4260)$

$0=120>2490-2290(>4440-4240)$

$0=160>2490-2200(>4440-4150)$

$0=200>2490-2180(>4440$

2166-2142(4115-4091)

RADIOCARBON AGE BP 3960 CALIBRATED AGE: cal BC 2470

Sample 0 and cal $B C$ (cal BP) ranges:

cal BP 4419

$0=20>2490-2465(>4439-4414)$

$0=60>2490-2461(>4439-4410)$

$0=60 \quad>2490-2457(>4439-4406)$

$0=80 \quad>2490-2453(>4439-4402) \quad 2424-2398(4373-4347)$

$0=100 \quad>2490-2340(>4440-4290)$

$=120 \quad>2490-2310(>4440-4260)$

$\begin{array}{lll}0=160 & >2490-2280(>4440-4230) & 2234-2209(4183-4158) \\ 0=200 & >2490-2190(>4440-4140) & 2157-2147(4106-4096)\end{array}$ 